\title{
KERAMICKÝ SOUBOR Z TRATI OHRADA U HRADU LICHNICE
}

\author{
KATEŘINA TĚSNOHLÍDKOVÁ - KAREL SLAVÍČEK - DALIBOR VŠIANSKÝ
}

\begin{abstract}
Abstrakt: Článek se zabývá zpracováním keramických nálezů z obléhací polohy v trati Ohrada u hradu Lichnice (okres Chrudim), která je spojována s obléhánim hradu v letech 1428-1429. Soubor tvoři 437 fragmentů kuchyňské a stolní keramiky. V rámci souboru bylo rozpoznáno 10 keramických tř́d. Část z nich byla vybrána $k$ identifikaci technologických vlastností a provenience prostřednictvím mikropetrografie. Výsledky byly ověreny pomoci $p X R F$. U vybraných fragmentů byla určena teplota výpalu. Vedle kuchyňské a stolni keramiky se studie věnuje nálezům keramiky kamnářské a stavebni, které nejsou pro lokalitu tohoto typu zcela běžné. Na vybraných fragmentech dlaždic a kachlů byla rovněž provedena mikropetrografická analýza.
\end{abstract}

Klíčová slova: Lichnice - obléhání-keramika-prírodovědné analýzy - 15. století.

\section{A pottery series from Ohrada, near the Lichnice castle}

Abstract: This article discusses the processing of pottery finds from the Ohrada site, near the Lichnice castle (Chrudim district) associated with the siege of the castle in 1428-1429. The series consists of 437 fragments of kitchenware and tableware. Ten ceramic classes were defined within the series. Some of the finds were selected for the identification of technological properties and provenance by means of micropetrography. The results were verified with the use of the pXRF method. Firing temperatures were determined with selected fragments. Apart from kitchenware and tableware, the study focuses on the finds of stove and building ceramics which are not typical of sites of this type. In addition, a micropetrographic analysis was conducted with selected fragments of floor tiles and tiles.

Key words: Lichnice - siege - pottery - natural science analyses - 15th century.

\section{1 Úvod}

V okolí hradu Lichnice (okres Chrudim) se nachází objekty spojené s jeho obléháním husity v letech 1428-1429, mezi nimi i výrazný terénní relikt nazývaný velitelské stanoviště nacházející se v trati Ohrada. Lokalita je známá již z přelomu 19. a 20. století a v minulosti jí byla věnována poměrně velká pozornost, přesto dva archeologické výzkumy provedené zde před více než 50 lety zůstaly nepublikovány (Sedláček 1900, 30; Klaus 1898, 7; Doležalová 2013, 27-44). Podkladem pro článek je diplomová práce autorky obhájená na Ústavu archeologie a muzeologie FF MU (Doležalová 2013).

V rámci studie byly vyhodnoceny nálezy kuchyňské a stolní keramiky ze tří archeologických akcí, které proběhly v areálu obléhacího stanoviště v trati Ohrada u Lichnice. Celkem se jednalo o 437 fragmentů. Soubor tvoří nálezy ze sondy V. Vokolka z roku 1968 (277 fragmentů) a sondy P. Rouse z roku 1977 (133 fragmentů). Soubor byl doplněn o nálezy z povrchového sběru ÚAM FF MU (27 fragmentů). Keramiku ze sond lze považovat za archeologicky homogenní, jelikož soubory pocházejí z nálezové situace na krátkodobě osídlené/využívané poloze, která je navíc úzce datována písemnými prameny i tvary archeologických reliktů. Díky tomu lze i poměrně nepočetný keramický soubor považovat za hodnotný.

Keramický soubor byl zpracován pomocí třístupňového systému. Základnímu vyhodnocení pomocí deskripčního systému a databázového zpracování byl podroben celý soubor. Poté byly systematicky vybrány fragmenty pro podrobnou makroskopickou deskripci. Výběr reflektoval obecné rysy souboru jako zastoupení keramických tříd a zároveň zohlednil zvláštnosti, například glazovanou keramiku či bílá jádra. $Z$ podrobné deskripce vyšel další výběr pro př́rodovědné analýzy, a to s cílem systematicky aplikovat metody analyzující chemické a petrografické složení vzorků. To umožnilo ověřit makroskopicky vyčleněné keramické třídy a zodpovědět otázky týkající se technologie výroby či provenience keramického materiálu. 


\section{Relikty obléhacích prací v okolí Lichnice}

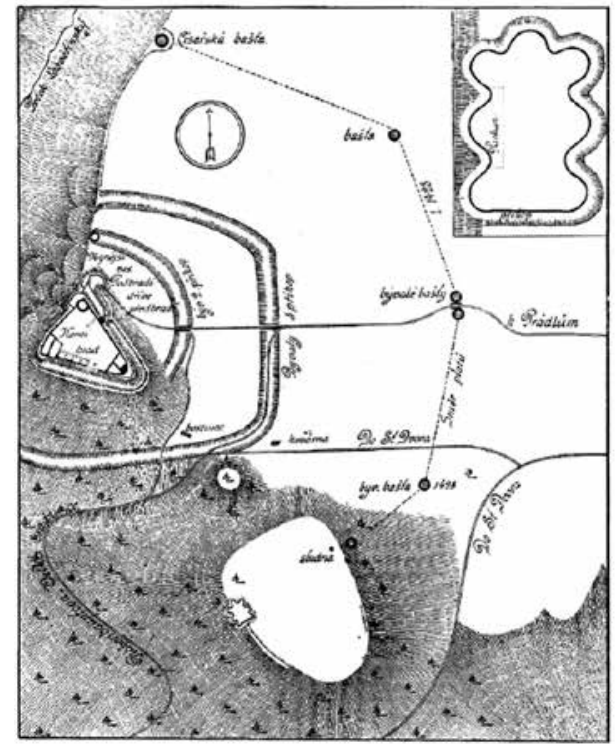

Obr. 1a. Plán obléhacího okruhu kolem hradu od A. Sedláčka (podle Sedláček 1900, 39). Na plánu je patrné umístění obléhacího stanoviště jihovýchodně od hradu. Vpravo nahoře ve výřezu plán obléhacího stanoviště.

Abb. 1a. Planskizze des Belagerungsrings um die Burg von A. Sedláček (nach Sedláček 1900, 39). Auf der Planskizze ist die Belagerungsstellung südöstlich von der Burg sichtbar. Rechts oben im Ausschnitt Planskizze der Belagerungsstellung.

skončení obléhání (Porák-Kašpar 1980, 205; Durdík 2009, 333; Doležalová 2013, 46-47).

Tzv. velitelské stanoviště není jediným dokladem obléhacích prací u Lichnice. Ve svahu nad Lovětínskou roklí se nachází několik reliktů v podobě plošin, které je možné interpretovat jako tzv. prakoviště (Doležalová 2013, 49-53, obr. 28). Stopy obléhacích prací měly být na počátku 20. století patrné také v prostoru mezi kopcem Štěpnice a Lovětínskou roklí - mělo jít o zbytky pěti bašt (Horák-Chramosta 1923; Sedláček 1900, 30; obr. 1a). V současnosti se je již nepodařilo dohledat (Frolík 2002, 399; Teplý 2005, 471).

\section{Př́rodní poměry a geologie lokality}

Hrad Lichnice se nachází v Železných horách. Poblíž Lichnice se táhne od severovýchodu k jihozápadu skalnatá Lovětínská rokle, k severozápadu vystupuje táhlý vrch Krkanka dosahující nadmořské výšky $567 \mathrm{~m}$. Geologická skladba okolí lokality je velmi komplikovaná (obr. 2). Stýká se zde totiž několik základních oblastí Českého masivu - bohemikum, moldanubikum a kutnohorsko-svratecká oblast. Ze severozápadu sem navíc zasahuje výběžek české křídové pánve Dlouhá mez (online Geologická mapa 1 : 50000 České geologické služby; Zelenka 2005, 55). Hrad se tyčí na hřebeni Železných hor, na jejich samotném jihozápadním okraji, nad údolím řeky Doubravy. Vrcholky Železných hor jsou tvořeny magmatickými a metamorfovanými horninami železnohorského plutonu (granity, granodiority a migmatity) a metamorfity čáslavského krystalinika (pararuly, migmatity). Podloží údolí tvoří křídové sedimenty. V blízkosti hradu, u Třemošnice, jsou to písčité slínovce a jílovce (místy silicifikované). Dále proti proudu řeky Doubravy se nachází též slínovce s polohami vápenců, jílovce, prachovce, pískovce (křemenné, 


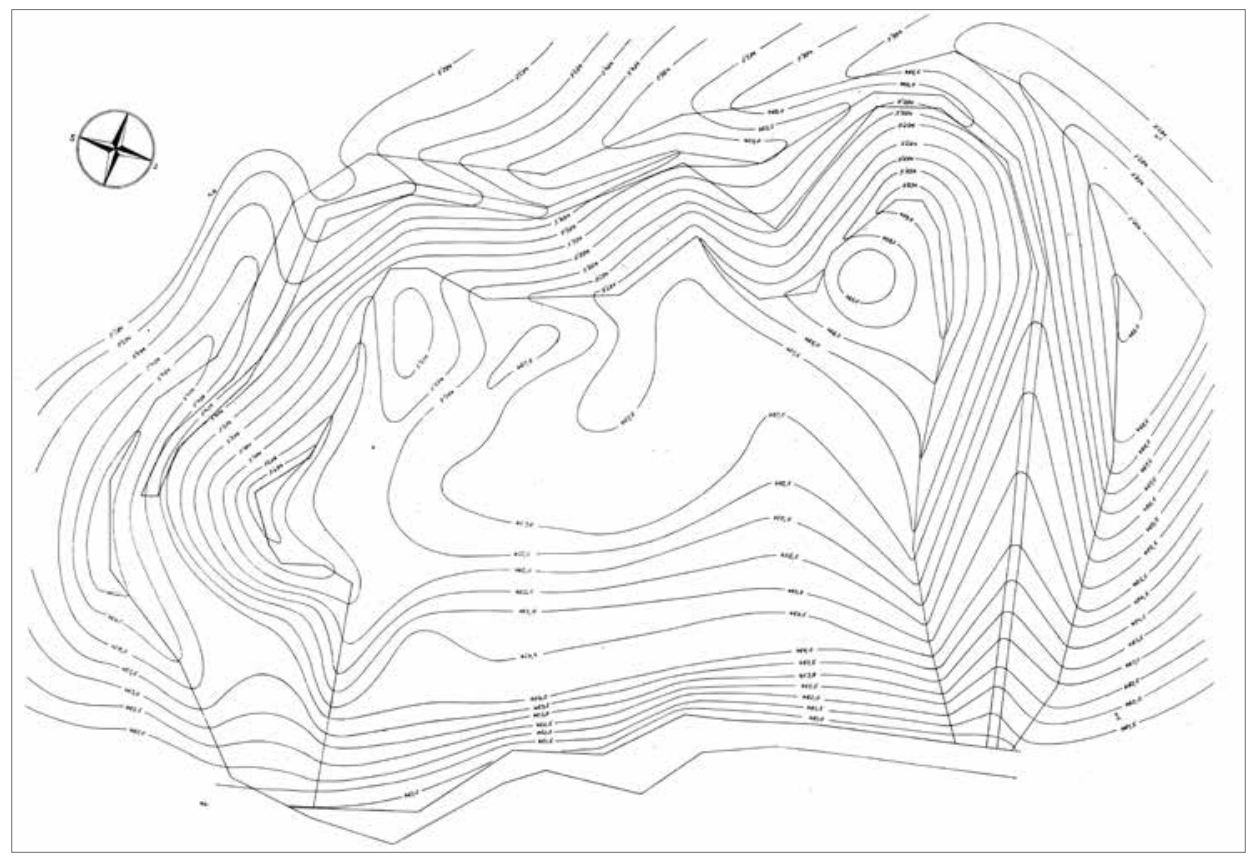

Obr. 1b. Geodetické zaměření lokality z roku 1968, autor V. Vokolek. Uloženo v Muzeu Vysočiny Havlíčkův Brod, upraveno. Abb. 1b. Geodätische Vermessung der Fundstelle aus dem Jahr 1968, erstellt von V. Vokolek. Aufbewahrt im Museum der Böhmisch-Mährischen Höhe Havlíčkưv Brod, bearbeitet.

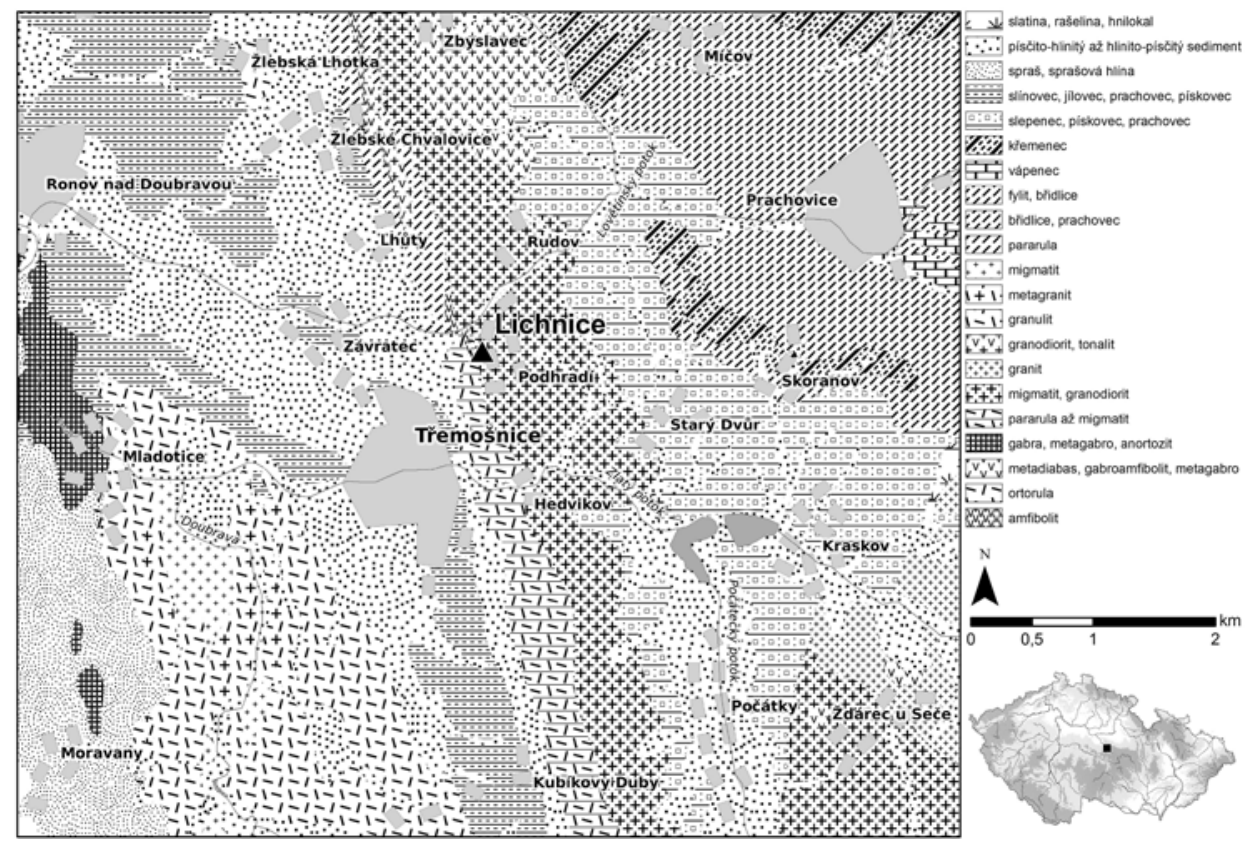

Obr. 2. Geologická mapa okolí Lichnice. Zdroj Geologická mapa 1 : 50000 České geologické služby, upraveno.

Abb. 2. Geologische Karte der Umgebung von Lichnice. Quelle Geologische Karte $1: 50000$ Tschechischer geologischer Dienst, bearbeitet. 
glaukonitické) i slepence. Na jihozápadním břehu Doubravy od Běstviny proti toku vystupují horniny moldanubika (granulity, metagranity, migmatity, pararuly, svorové ruly). U Ždírce nad Doubravou protéká Doubrava též hlubinnými vyvřelinami bohemika (anortozit, gabro, peridotit, troktolit) a metamorfity (amfibolit).

\section{Archeologické výzkumy v trati Ohrada u Lichnice s důrazem na nálezy keramiky}

První sonda byla provedena 13.-20. srpna roku 1968 pod vedením V. Vokolka z Muzea východních Čech v Hradci Králové (obr. 3, 4, 5). V rámci výplně byla popsána pouze jedna vrstva, a to rezavě hnědá hlína. U nálezů byla zaznamenána jejich vzdálenost od počátku sondy a hloubka. Soubor nálezů tvoří 277 fragmentů kuchyňské a stolní keramiky. Dále bylo nalezeno šest fragmentů dlaždic a 16 fragmentů nádobkových kachlů. Jediné kovové artefakty představují dvě střely. Zbylou část nálezů tvoří drobné uhlíky a šest zlomků zvířecích kostí.

Asi 2-3 m od počátku sondy byla odkryta destrukce zídky, která se nacházela u skalního podloží (obr. 4, obr. 5a; jako začátek sondy je brána severní strana). V. Vokolek zídku interpretoval jako opevňovací. Zbytky další zdi se měly nacházet asi 7,5-9,5 m od počátku sondy (obr. 4, obr. 5b). Druhá zed' se nachází na kraji terénní nerovnosti vytvářející v objektu prohlubeň. Hypotetická rekonstrukce průběhu zdi kolem této prohlubně pak vedla V. Vokolka k možné interpretaci jako zbytku podezdívky stavby. Vzhledem k nízkému výskytu dalšího kamení na lokalitě by mohlo jít o podezdívku dřevohlinité konstrukce. V délce $11,5-12 \mathrm{~m}$ bylo odkryto skalní podloží. Maximální hloubka sondy dosáhla $1 \mathrm{~m}$.

V roce 1977 položil druhou sondu na lokalitě P. Rous z Regionálního muzea Vysočiny v Havlíčkově Brodě. K sondě není žádná další dokumentace, její přibližné umístění bylo autorem výzkumu dohledáno v roce 2012 a označeno na mapě (obr. 6). Byl získán soubor kuchyňské a stolní keramiky a několik kovových předmětů, včetně militarií (dva kusy hřebíků, stavební kování, nůž a kroužek, který by snad mohl pocházet z brnění). Při tomto výzkumu bylo získáno 133 fragmentů keramiky. Složení souboru je ovlivněno výběrem charakteristických fragmentů při výzkumu - pouze $5 \%$ souboru tvořily nezdobené výdutě a převažují okraje $64 \%$ (Doležalová 2013, 134, graf 3).

K těmto nálezům bylo pro zpracování přidáno ještě 27 fragmentů kuchyňské a stolní keramiky a 13 fragmentů dlaždic získaných při povrchové prospekci lokality Ústavem archeologie a muzeologie FF MU v Brně v dubnu 2012.

Vedle těchto výzkumů proběhlo na lokalitě v posledních letech několik povrchových prospekcí vyvolaných především poničením lokality hledači s detektory kovů. $Z$ těchto akcí byl rovněž publikován keramický materiál (167 fragmentů kuchyňské a stolní keramiky; FrolíkMusil 2013, 125-214; Musil 2013, 87-111). Vzhledem k tomu, že základní zpracování keramiky $\mathrm{v}$ této studii proběhlo ještě před publikováním tohoto souboru, je tento soubor použit pouze ke srovnání a neslouží jako východisko pro základní zpracování.

\section{Kuchyňská a stolní keramika - základní deskripce a metody podrobného makroskopic- kého popisu}

\subsection{Základní zpracování souboru pomocí deskripčního systému a databáze}

Keramika z obléhací polohy byla zanesena do databáze s využitím deskripčního systému. Použitý deskripční systém pracuje s rozšířenou verzí popisu technologických vlastností keramiky (včetně keramických tříd) ve shodě s principy operačního řetězce (např. Roux 2011, 80; 2017; Čapek et al. 2018, 23-24). V popisu technologických aspektů vychází z aktuálních zahraničních deskripčních systémů a znalosti středověké keramiky v našem prostředí (např. Kaltenberger 2009, 404-406; Hofer et al. 2010, 10-24; Procházka 2007, 234-270).

Deskripční systém pracuje s popisem keramiky, jejího povrchu, lomu, případně čerstvého lomu či řezu, pozorování vlastností probíhá makroskopicky nebo pomocí lupy. Pro popis barev 


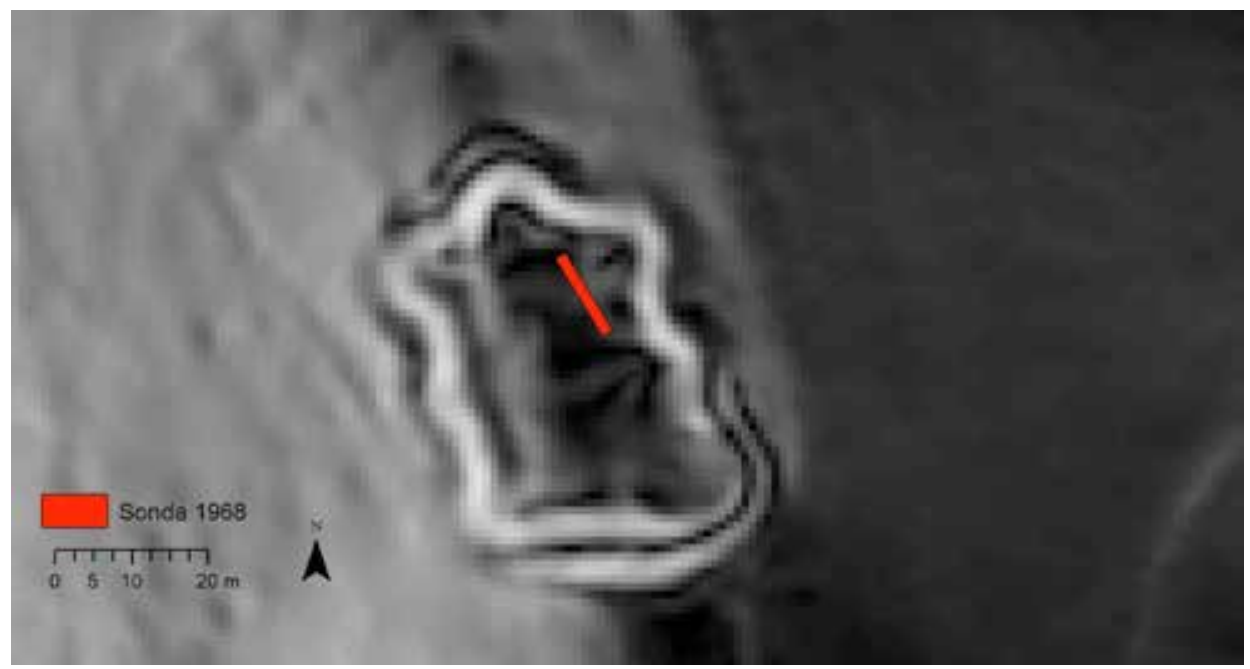

Obr. 3. Umístění sondy V. Vokolka z roku 1968.

Abb. 3. Lage der von V. Vokolek vorgenommenen Sondiergrabung aus dem Jahr 1968.

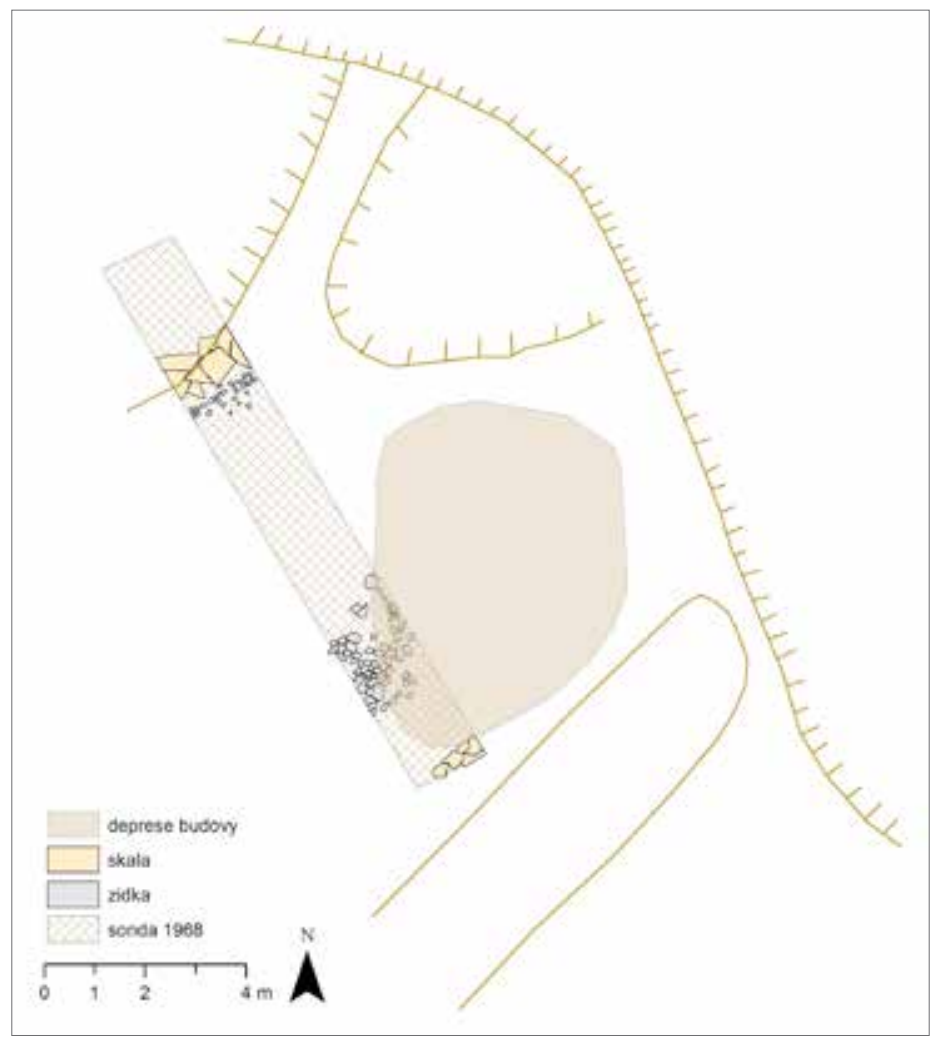

Obr. 4. Situace odkrytá v sondě z roku 1968. Počátek sondy (vzdálenost 0) je v severní části. Dokumentace je uložena v Muzeu Vysočiny Havlíčkův Brod, upraveno podle nákresů V. Vokolka.

Abb. 4. Bei der Sondiergrabung 1968 freigelegte Situation. Der Anfang der Sondiergrabung (Entfernung 0) liegt im nördlichen Teil. Die Dokumentation wird im Museum der Böhmisch-Mährischen Höhe Havličkův Brod aufbewahrt, bearbeitet gemäß den Skizzen von V. Vokolek. 

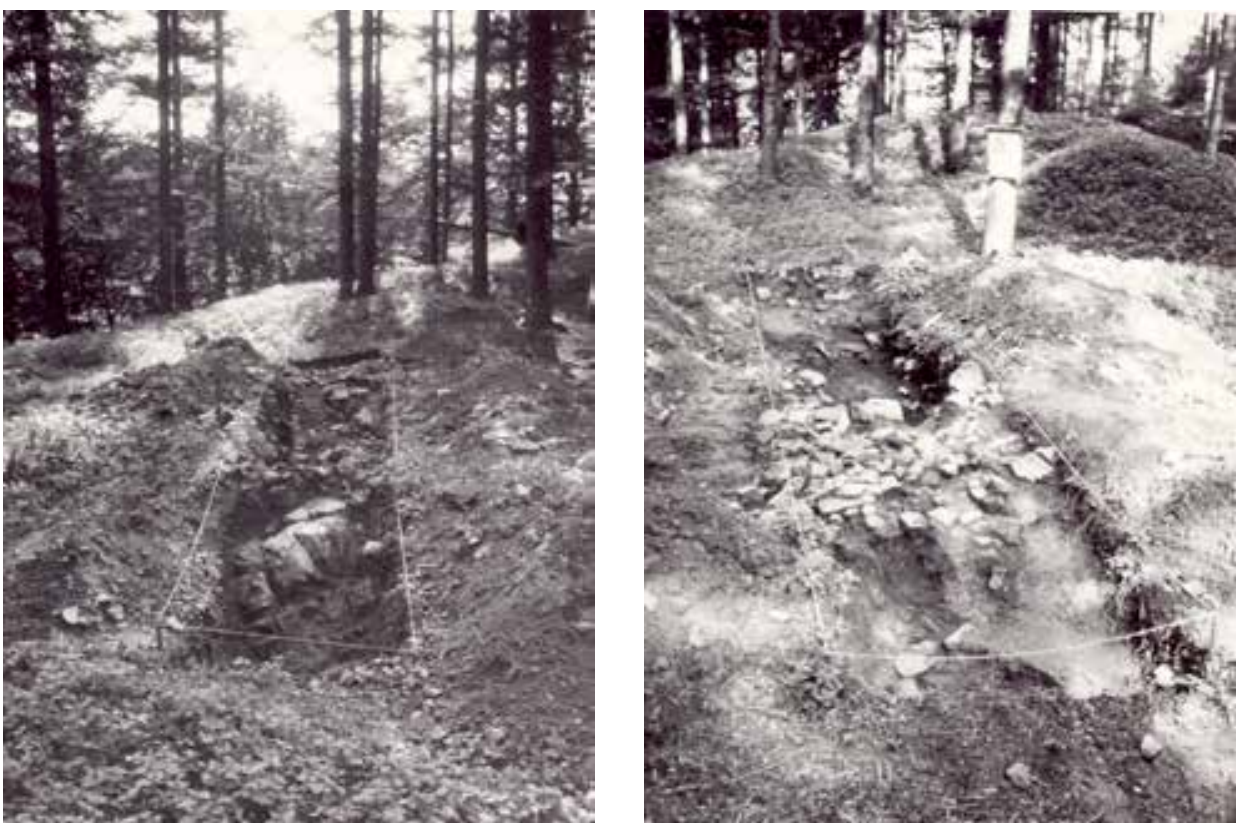

Obr. 5. Fotografická dokumentace sondy z roku 1968: a - skalní podloží, u kterého se nacházela destrukce menší zídky v přední části sondy; b - destrukce zdi v zadní části. Dokumentace je uložena v Muzeu Vysočiny Havlíčkův Brod.

Abb. 5. Fotodokumentation der Sondiergrabung aus dem Jahr 1968: a - Felsenuntergrund, bei dem sich die Zerstörungsschicht einer kleineren Mauer im vorderen Teil der Sondiergrabung befindet; $b$ - Zerstörungsschicht im hinteren Teil. Die Dokumentation wird im Museum der Böhmisch-Mährischen Höhe Havlíčkův Brod aufbewahrt.

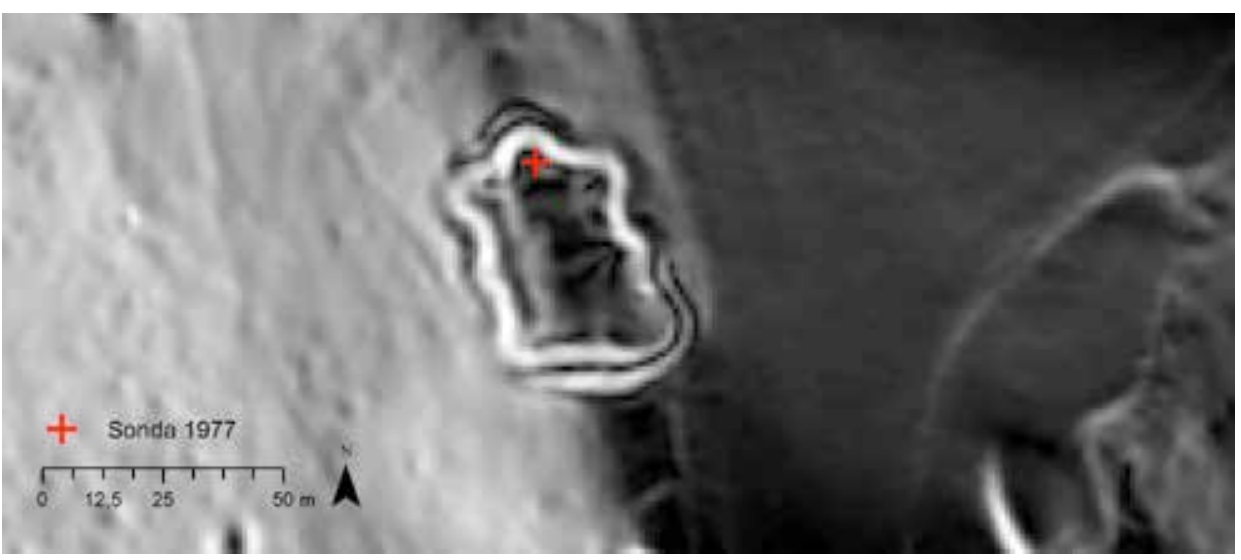

Obr. 6. Umístění sondy P. Rouse z roku 1977.

Abb. 6. Lage der Sondiergrabung von P. Rous aus dem Jahr 1977.

či tvrdosti lze použít škály - např́iklad Munsellovu barevnou škálu či zjednodušenou Mohsovu stupnici tvrdosti (Orton-Hughes 2013, 283). Bylo provedeno pouze základní statistické vyhodnocení. Jako kvantifikátor byl zvolen počet fragmentů (Nováček et al. 2010, 302-304; OrtonTyers-Vince 1993, 166-181).

Součástí základní deskripce je vyčlenění keramických tříd. Tento koncept, který je od konce 20. století standardem při zpracování středověké keramiky, se stal v poslední době předmětem 
kritiky (podrobně Doležalová 2015, 39-66). Přibývá studií ukazujících na nedostatečnost makroskopického určení tříd a problematiku kompatibility aplikace př́rodovědných analýz pro jejich přesnější definici či určení správného vyčlenění (napřr. Matějková 2014, 89-117). Protože i v tomto případě bylo jedním z cílů přírodovědných analýz potvrzení keramických tříd, pokusili se autoři věnovat maximální pozornost výběru vzorků a podrobné definici výzkumných otázek včetně diskuze nad tím, na jaké otázky mohou analýzy účinně odpovědět, tak aby odpovědi byly použitelné při dalším archeologickém výzkumu.

\subsection{Podrobná makroskopická deskripce}

Pro druhý stupeň zpracování bylo vybráno 29 fragmentů (včetně jednoho kachle). Část vzorků byla vybrána se záměrem ověření vyčleněných keramických tříd (pouze početnější tř́ídy 1, 2, 3, 6, 7 - nad 20 fragmentů). Několik vzorků bylo vybráno vzhledem k výskytu zvláštních technologických znaků (např. bílého jádra, glazury).

Při zpracování byly použity dvě základní metody, a to podrobná makroskopická deskripce nábrusů keramiky a přepalování vzorků v laboratorních podmínkách. Obě metody jsou destruktivní. Nábrusy lze použít k přesnějšímu makroskopickému popisu vlastností či popisu pomocí stereomikroskopu s menším zvětšením, určení tvaru, procentuálního zastoupení ostřiva či pórů pomocí škál, základnímu petrografickému určení ostřiva, určení tvrdosti ostřiva pod stereomikroskopem, určení technologie formování a konfrontaci s makroskopicky vyčleněnými třídami. Pro popis je užíváno spíše menší zvětšení (max. 10-20×; Allan-Langman 2002, 65; Daszkiewicz-Baranowski 2011, 42).

Druhou metodou je přepalování vzorků; to spočívá v nařezání keramiky na tenké plátky a jejich výpalu v laboratorní peci na určité teploty (v našem případě v oxidačních podmínkách na teploty $800,900,1000,1100$ a $1200{ }^{\circ} \mathrm{C}$ s nárůstem $100{ }^{\circ} \mathrm{C}$ za hodinu a výdrží 60 minut na maximální teplotě). Při přepalování vzorků dochází ke změně barev keramické hmoty, která vypovídá především o charakteru pojiva - obsahu železa, vápníku či smíchání různých druhů hlín. U oxidačně pálené keramiky lze přepalováním určit orientační teplotu výpalu a tepelnou výdrž materiálu. Přepalování může poukázat na určité vlastnosti ostřiva: železité ostřivo, př́měs šamotu z jiného jílu, ostřrivo vyhořívající při určitých teplotách či měnící barvu (odhalení těchto vlastností může pomoci stanovení výzkumných otázek, definování keramických tříd a výběru vzorků pro př́ŕrodovědné analýzy; Daszkiewicz-Schneider 2011, 78-84; Daszkiewicz 1998, 258-264; Johnson et al. 1988, 403-414; Abbink 1999, 91-108).

\subsection{Keramické třídy}

Keramické třídy (dále jen KT) byly vyčleněny na základě výše analyzovaných technologických znaků (obr. 7, popis KT viz př́loha č. 1).

Keramické třídy 1 a 7 jsou charakteristické vystupujícím písčitým, patrně křemenným ostřivem z povrchu keramických fragmentů. U KT 1 je barva povrchu šedá, často spíše světlé odstíny. Keramická třída 7 má barvu béžovou až středně hnědou. U KT 1 lze předpokládat, že původní barva povrchu byla tmavě šedá a že je rovněž zástupcem zakuřované keramiky. Nábrusy u ní prokázaly výskyt bílých jader. Dalši tři tř́idy charakterizuje úprava jejich povrchu (KT 3, 5 a 8). Jde o keramiku s povrchem upraveným leštěním, poslídováním či glazováním. Keramická třída 5 - poslídovaná - byla původně v souboru zjištěna ve vyšším počtu, později byla podrobena revizi, protože se ukázalo, že většinou slída ulpěla na povrchu spíše z okolí, než že by šlo o nějakou cílenou úpravu povrchu. Svědčí o tom i skutečnost, že ve skupině jsou zastoupeny pouze hrnce (Doležalová 2013, 142). Keramická třída 4 byla definována na základě středního až vysokého obsahu slídy v keramickém těstě. Dvě třídy definoval oxidační výpal - KT 9 - oxidační červená a KT 10 - oxidační světlá. Keramická tř́ída 6 je klasická redukčně pálená keramika středně až tmavě šedé barvy bez světlého jádra. Poslední, KT 2 představuje keramika drolivé struktury pravděpodobně ne př́liš kvalitního smíšeného až redukčního výpalu, její barva se 
pohybuje nejčastěji v odstínech hnědošedé, v některých případech obsahuje černá jádra či oxidační přežah povrchu.

Po přepálení na vybrané stupně se jako nejvýrazněji odlišná ukázala KT 3. Její pojivo patrně obsahuje méně oxidů železa, tak se i při nejvyšší teplotě $1200^{\circ} \mathrm{C}$ barví do béžova až lehce oranžova. Na rozdíl od ostatních vzorků, které jsou tmavě hnědočervené (s výjimkou KT 10, která je při oxidačním výpalu béžová/krémová, ale vzhledem k nízkému početnímu zastoupení v souboru nebyla analyzována). Stejně tak na nábrusech je hmota KT 3 oproti ostatním jemnější, bez větších kousků ostřiva. Světlé jádro a tmavý povrch potvrzují, že se jedná o zakuřovanou keramiku.

Vzorky KT byly vybrány na ověření přírodovědnými metodami. Vedle toho je bylo možné konfrontovat s osmi technologickými skupinami, které byly vyčleněny při zpracování keramiky z trati Ohrada a jejího okolí (Frolík-Musil 2013, 164-166; Musil 2013, 92-101). Větší část skupin bylo možné ke KT přiřadit (tab. 1). Srovnání však ukázalo zásadní rozdíl v obou souborech ve výskytu keramiky s vysokou př́měsí slídy - v našem souboru byla minoritní a v publikovaném souboru převažovala $55 \%$. Pravděpodobně se při popisu obsahu slídy projevila subjektivita makroskopického popisu. Za předpokladu, že rozdíl ve výskytu slídového zboží byl skutečně způsoben subjektivitou popisu, mohly by k redukčnímu zboží s výraznou příměsí slídy patřit i některé z KT 1, 2, 6 a 7. Toto srovnání ukazuje skutečnost, že tento způsob popisu neumožňuje vzájemné srovnání technologických znaků obou souborů. Pomohly by patrně kvalitní makrofotografie technologických skupin/KT či př́stupný vzorník.

\begin{tabular}{|c|c|c|l|l|}
\hline KT & $\begin{array}{c}\text { Počet } \\
\text { fragmentů }\end{array}$ & $\begin{array}{c}\text { Procentuální } \\
\text { zastoupení }\end{array}$ & Keramické tvary & $\begin{array}{l}\text { Odpovídající technologická skupina } \\
\text { podle Musil 2013, 92-101 }\end{array}$ \\
\hline 1 & 133 & 30,4 & $\begin{array}{l}\text { hrnec, poklička, mísa, } \\
\text { kahan }\end{array}$ & hrubší zboží modrošedých tónů \\
\hline 2 & 79 & 18,1 & $\begin{array}{l}\text { hrnec, poklička, džbán, } \\
\text { mísa, kahan }\end{array}$ & hrubší zboží modrošedých tónů \\
\hline 3 & 65 & 14,9 & hrnec, poklička, pohár & $\begin{array}{l}\text { redukční zboží s jemným kožovitým } \\
\text { povrchem }\end{array}$ \\
\hline 4 & 13 & 3 & hrnec, poklička, kahan & redukční zboží s výraznou příměsí slídy \\
\hline 5 & 19 & 4,3 & hrnec & redukční zboží s výraznou příměsí slídy \\
\hline 6 & 93 & 21,3 & $\begin{array}{l}\text { hrnec, poklička, pohár, } \\
\text { kahan }\end{array}$ & hrubší zboží modrošedých tónů \\
\hline 7 & 21 & 4,8 & hrnec & hrubší zboží modrošedých tónů \\
\hline 8 & 1 & 0,2 & - & - \\
\hline 9 & 2 & 0,5 & pohár/džbán & - \\
\hline 10 & 11 & 2,5 & džbán & světlé oxidační zboží \\
\hline
\end{tabular}

Tab. 1. Keramické tř́ídy - počet fragmentů a procentuální zastoupení v souboru, zastoupení keramických tvarů a korelace se skupinami J. Musila. Podle Musil 2013, 92-101.

Tab. 1. Keramikklassen - Anzahl der Fragmente und prozentuales Vorkommen in der Kollektion, Vorkommen der Keramikformen und Korrelation mit den Gruppen von J. Musil. Nach Musil 2013, 92-101.

\subsection{Technologická charakteristika souboru}

Technologická charakteristika byla vytvořena na základě výše uvedených metodologických postupů a kombinuje výsledky metod 1. a 2. stupně zpracování keramiky. Výsledky př́rodovědných analýz jsou ponechány zvlášt’ pro možnost konfrontace s výsledky makroskopického popisu (ta je provedena v závěru článku v Diskuzi). 


\section{Složeni hmoty a formování}

Složení keramické hmoty reflektují vyčleněné KT. Většina keramiky byla středně zrnitá, část jemnozrnná. $Z$ příměsí byla u části zboží identifikována příměs slídy. Běžná byla př́iměs písku, který byl s největší pravděpodobností součástí keramické suroviny. U pojiva byly makroskopicky rozeznány různé druhy keramického těsta (nebo keramických hlín), větší část se při oxidačním výpalu barvila do červena ( KT1, 2, 5, 6, 7 a 9 obsahovaly oxidy železa), u zbylé části zůstávalo světlé - krémové či béžové zbarvení (u KT3 a 10). V některých fragmentech (u KT 1, $2,3)$ jsou na nábrusech patrné závalky jiné hmoty či špatně rozpracovaná hlína.

Pokud bylo možné pozorovat stopy po výrobě na těle nádoby, šlo o stopy po vytáčení na rychle rotujícím kruhu v podobě rýh či otisků papilárních linií, v některých případech byla patrná nerovnoměrná tloušt'ka stěn nádoby způsobená různým tlakem na stěny nádoby při vytáčení. Ve dvou př́ípadech bylo možné rozpoznat dolepený okraj (u KT 7), kdy hrnčíři zřrejmě nezbyla hlína na dotvoření nádoby nebo okraj záměrně vyformoval ze zvláštního kusu hlíny dolepeného na závěr na nádobu (obr. 7). Více výrobních stop bylo možné pozorovat na dnech nádob či úchytkách pokliček. Jeden fragment

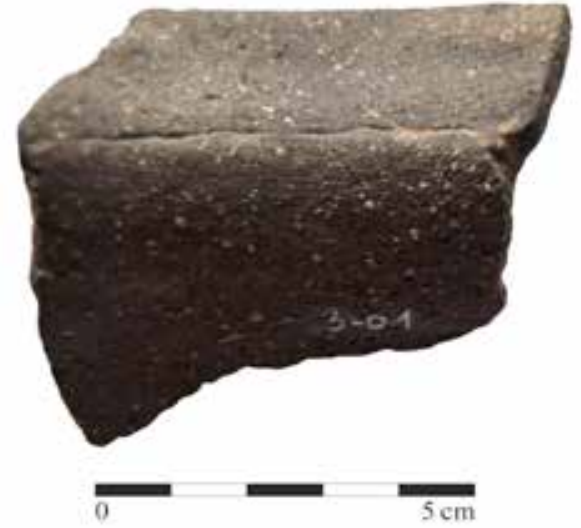

Obr. 7. Technologický znak - dolepený okraj k nádobě, přír. č. 03-01, 03-02; KT 7.

Abb. 7. Technologisches Merkmal - angekleber Gefäßrand, Akquis.- Nr. 03-01, 03-02; KT 7. šedé, mělo na lomu/řezu bílé jádro - vzorek této keramiky byl vybrán na další analýzu s otázkou týkající se technologie výroby. Předpokladem bylo, že jde o keramiku se zakuřovaným povrchem a že bílé jádro mohla způsobit vysoká teplota výpalu či kaolinová hmota. Přepalování vzorků ukázalo, že všechny různě barevné vrstvy na keramice v souboru včetně bílého jádra vznikly při výpalu či jako důsledek používání nebo postdepozičních procesů.

Z povrchových úprav se na keramice objevilo leštění (KT 3), poslídování (KT 5) a na jednom fragmentu glazura (KT 8). Dalším předmětem analýzy bylo určení druhu glazury. Jde o tmavě zelenou glazuru (Munssel 5GY 3/2) na vnitřní straně fragmentu světle hnědošedé barvy. Za tímto účelem byl analyzován vnější povrch fragmentu (inv. č. 35-14). Podle výsledku pXRF analýzy se jedná o olovnatou glazuru.

\section{Použivání a transformační procesy}

Stopy po používání jsou v souboru zastoupeny na sedmi keramických fragmentech, na kterých se dochovaly stopy po organických zbytcích v podobě uhelnatých prř́škvarků. Z výskytu několika lehce přepálených fragmentů nelze vyvozovat podrobnější závěry.

Postdepoziční procesy lze nejlépe sledovat na abrazi keramiky. Ta se většinou týká zaoblených hran většiny fragmentů (slepitelnost je minimální). V některých případech vlivem úplného 
setření vnitřního a vnějšího povrchu zůstal z fragmentu jen skořápkovitý relikt. Tyto fragmenty se koncentrují v KT 1 a 7 - jejich makroskopické vytrrídění patrně tato vlastnost ovlivnila a vyskytují se převážně v horních vrstvách sondy. Lze předpokládat, že k jejich poškození došlo působením vody/vlhkosti a zčásti také nevhodnou metodou umývání, kdy na některých fragmentech můžeme pozorovat stopy po drhnutí kartáčem (obr. 8). Nízká odolnost povrchu u těchto tř́d mohla být dána i technologií jejich výroby.
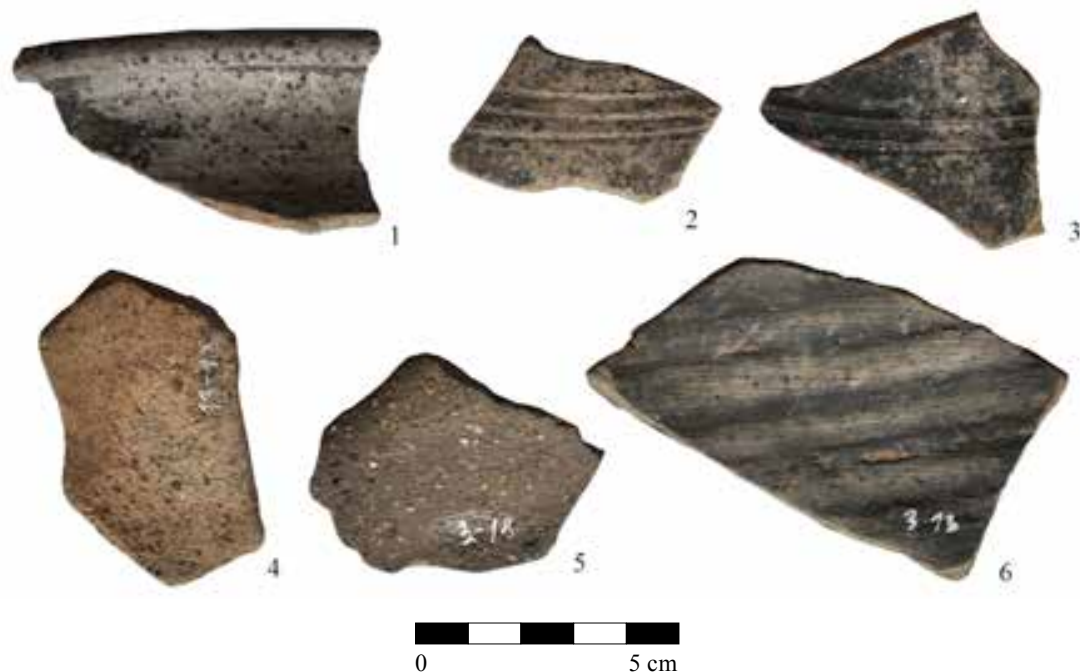
,

0

$5 \mathrm{~cm}$

Obr. 8. Fragmenty keramiky s povrchem poškozeným působením klimatických podmínek či transformacemi sensu stricto. Př́írůstková čísla: 1 - 01-03 (KT 1); 2 - 36-46 (KT 1); 3-14-04 (KT 1); 4 - 13-13 (KT 1); 5 - 03-18 (KT 7); 6 - 03-13 (KT 1). Abb. 8. Keramikfragmente mit durch Einwirkung der klimatischen Bedingungen oder durch Transformationen sensu stricto beschädigter Oberfläche. Akquisitionsnummern: 1 - 01-03 (KT 1); 2 - 36-46 (KT 1); 3 - 14-04 (KT 1); 4 - 13-13 (KT 1); 5-03-18 (KT 7); 6-03-13 (KT 1).

\subsection{Morfologie souboru}

Tvary nádob, ze kterých pocházely fragmenty, bylo možné určit u 142 fragmentů - z toho bylo 126 okrajů nádob. Ze 142 fragmentů bylo slepeno 101 kusů. Mezi nálezy převažovaly hrnce (65\%), ve větší míře se zde nacházely pokličky (18\%). Několika fragmenty jsou doloženy kahany (7\%), džbány (4\%), poháry (4\%) a misky ( $2 \%)$. Soubor není natolik početný, aby bylo možné sledovat podrobněji vazbu tvarů na KT (Doležalová 2013, 148).

Z 56 fragmentů hrnců bylo možné zjistit, že jejich průměr byl nejčastěji mezi $16-20 \mathrm{~cm}$. U žádného z hrnců nebylo možné určit celkový tvar nádoby (obr. 9). Nejvíce se v souboru vyskytovaly okraje přehnuté (49 fragmentů před slepením, 33 kusů po slepení) a jednoduché ( 24 fragmentů, 20 kusů). Ve větším počtu se vyskytly ještě okraje jednoduché vně vyhnuté (16 fragmentů, 12 kusů). Další okraje se již vyskytovaly v počtu deset a méně fragmentů; vodorovně vyložené, okruží, nepravá okruží, ovalené, jednoduché zahnuté a zavinuté. Římsovité a nepravé římsovité okraje se v souboru nevyskytují (př́iloha č. 2).

Celý hrnec, který by měl pocházet z trati Ohrada, se nachází v muzeu na hradě Lichnice. V roce 2009 byl vyzvednut a předán detektorářem kastelánce hradu (obr. 10). Okraj hrnce je přehnutý. Stěny hrnce nesou znaky po vytáčení na rychle rotujícím hrnčířském kruhu. Technologicky patří hrnec do KT 6.

Z osmnácti dochovaných fragmentů či slepených kusů se nejkompletněji dochovala zvonovitá poklička z výzkumu P. Rouse. Výška pokličky patřící KT 6 byla $55-60 \mathrm{~mm}$, průměr 


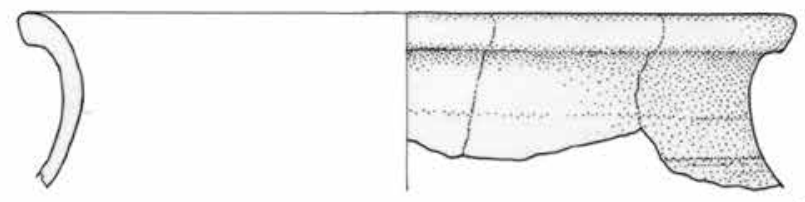

1

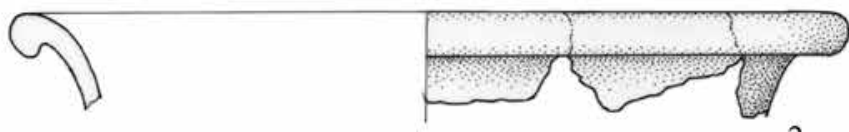

2

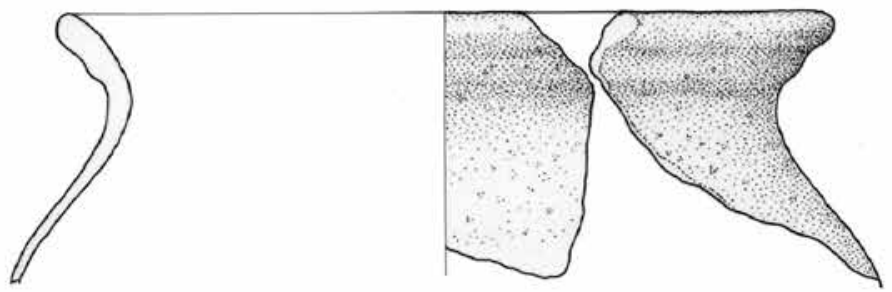

3
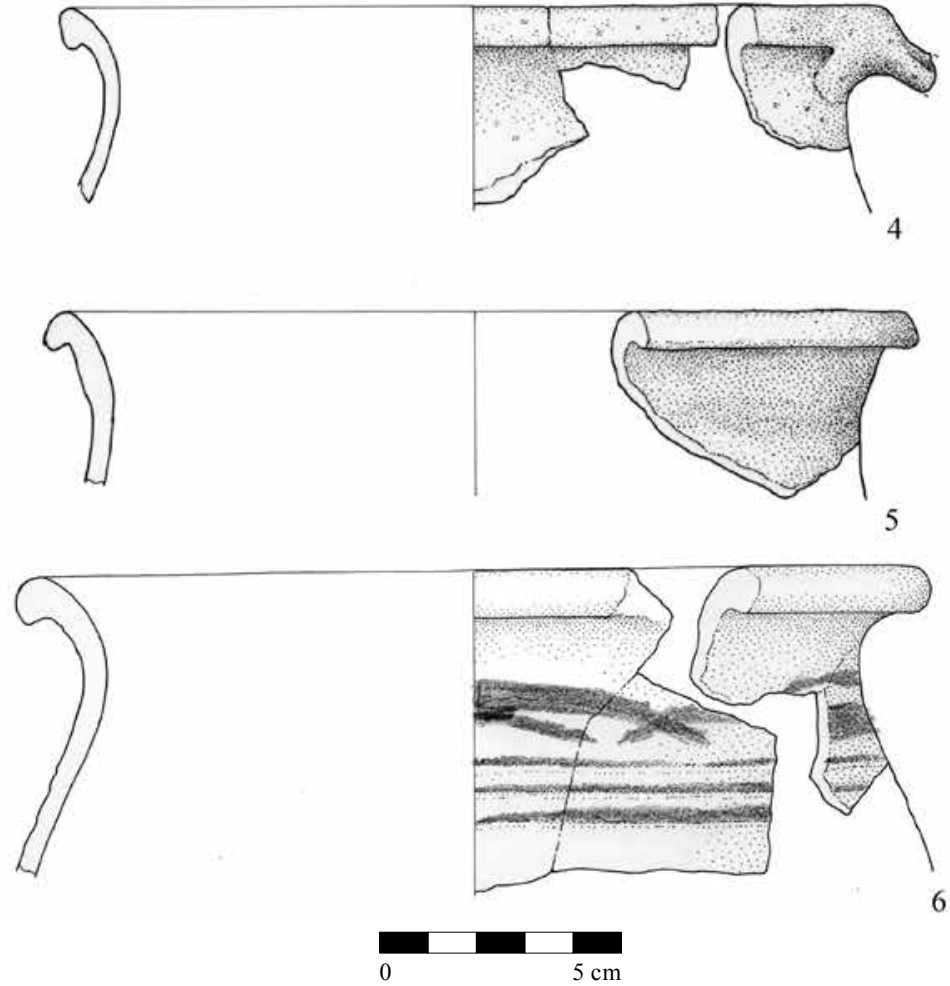

Obr. 9. Výběr fragmentů hrnců z trati Ohrada u Lichnice (autorka kresby Soňa Plchová). Př́růstková čísla: 1 - 35-13, 35-15, 35-22 (KT 5); 2 - 37-04, 37-05, 37-06 (KT 5); 3-03-01, 03-02, 03-03, 03-04, 03-06 (KT 7); 4-36-01, 37-07, 37-08, 37-11, 37-13 (KT 1), 5-36-06, 36-43 (KT 5); 6-35-10, 35-11, 35-12, 37-01, 37-02 (KT 3).

Abb. 9. Auswahl an Topffragementen von der Lage Ohrada bei Lichnice (Zeichnung Soňa Plchová). Akquisitionsnummern: 1-35-13, 35-15, 35-22 (KT 5); 2 - 37-04, 37-05, 37-06 (KT 5); 3-03-01, 03-02, 03-03, 03-04, 03-06 (KT 7); 4-36-01, 37-07, 37-08, 37-11, 37-13 (KT 1), 5 - 36-06, 36-43 (KT 5); 6-35-10, 35-11, 35-12, 37-01, 37-02 (KT 3). 


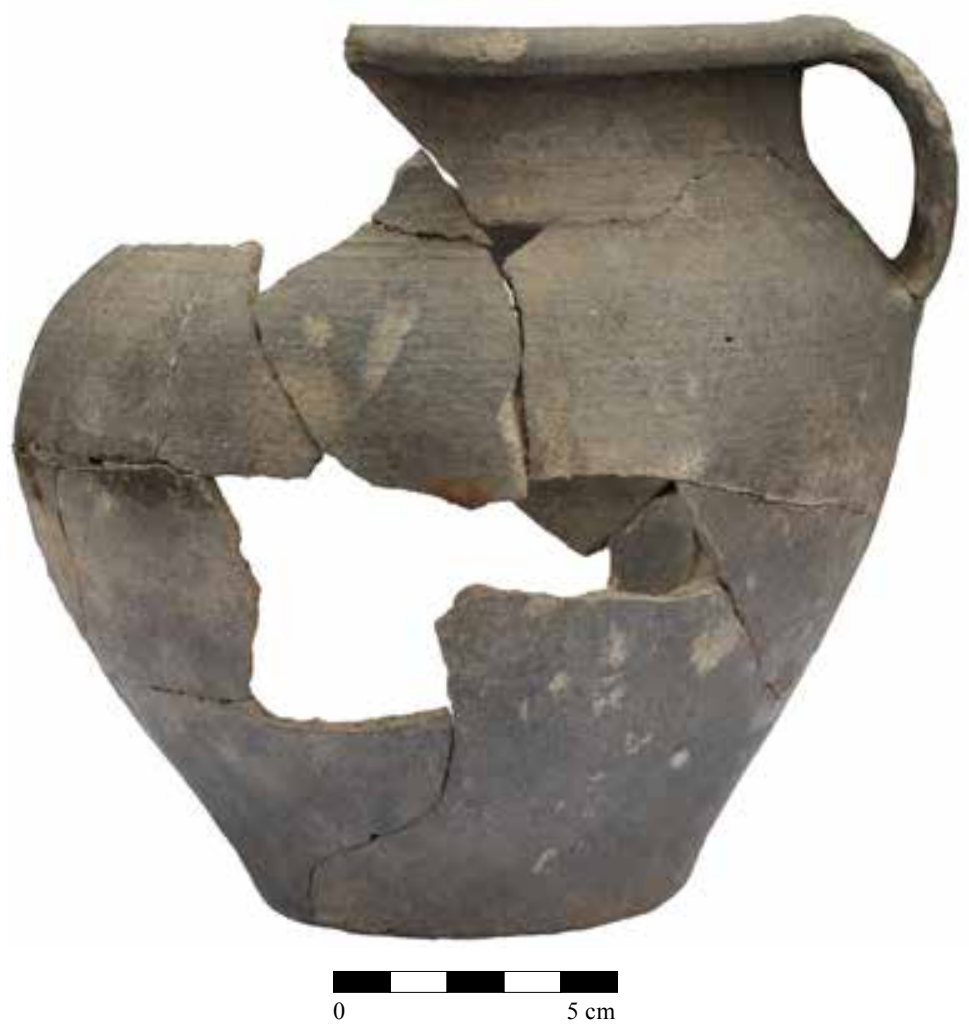

Obr. 10. Hrnec nalezený detektorářem, pravděpodobně v místech obléhacího stanoviště v trati Ohrada.

Abb. 10. Von einem Metalldetektorsucher wahrscheinlich an den Stellen der Belagerungsstellung in der Lage Ohrada entdeckter Topf.

160-180 mm a průměr úchytky $35 \mathrm{~mm}$ (obr. 11). Dále se dochovaly dva fragmenty úchytek zvonovitých poklic, jeden z nich o průměru $34 \mathrm{~mm}$. Zbytek představují fragmenty okrajů. Další skupinu nádob představuje sedm fragmentů okrajů kahanů či nízkých misek. Jako další keramický tvar byly rozpoznány fragmenty dvou velkých misek.

Picí keramika je zastoupena několika fragmenty džbánů a pohárů. Z kompletnějších tvarů se dochoval kus světlého džbánu z jemné hlíny s páskovým uchem a průměrem okraje $14-16 \mathrm{~cm}$ (obr. 12:3). Z drobnějších tvarů se zachoval okraj s částí výdutě jednoho pohárku či džbánku zdobeného radélkem $\mathrm{v}$ podobě jedné řady kosočtverců a druhého zdobeného žlábky, v obou př́ipadech s průměrem okraje $8-10 \mathrm{~cm}$ (obr. 12:1, 2). Fragmenty pohárů patří KT 3 a 6 . Jde o KT keramiky s leštěným povrchem a keramiky s vysokým obsahem slídy v keramickém těstě, tedy specifické KT s lesklým povrchem. Džbány lze připsat KT 2 a 10.

Méně početný soubor zpracovaný J. Musilem tvarovým složením koresponduje se zde zpracovaným souborem, z tvarového spektra navíc autor identifikoval trojnožku s vnitřní transparentní glazurou a závěsný kahan (Musil 2013, 92-101).

Výzdoba se objevila celkem na 44 fragmentech (slepitelných do 38 kusů; typáře viz Doležalová 2013, tab. 30-32). Kromě dvou př́ípadů, kdy se výzdoba nacházela v okraji, je výzdoba vždy umístěna na těle nádoby, nejčastěji v její horní polovině. Objevily se tř́ základní typy výzdoby: na 32 fragmentech žlábky, někdy v kombinaci s lištou, v osmi prrípadech otisk radélka a ve čtyřech vrypy. Pokud bylo možné určit keramický tvar, patřily zdobené fragmenty džbánu, 


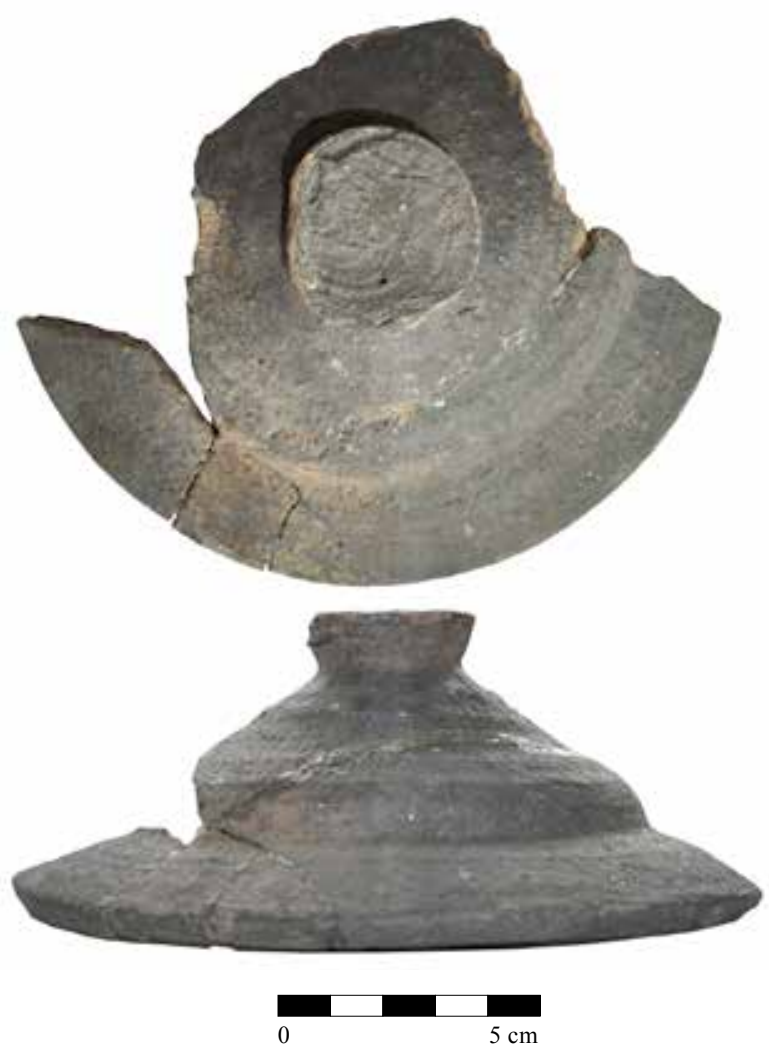

Obr. 11. Poklice z trati Ohrada u Lichnice. Př́ŕi̊stková č́́sla: 35-06, 35-07, 37-12, 37-28, 37-29 (KT 6). Abb. 11. Deckel von der Lage Ohrada bei Lichnice. Akquisitionsnummern: 35-06, 35-07, 37-12, 37-28, $37-29$ (KT 6).

patrně poháru, misce a většina fragmentů hrncům. Výzdoba jedním až třemi žlábky se objevila u KT 1-6 a 10. Nejčastějším výzdobným motivem jsou tři žlábky nad sebou. Radélková výzdoba se nachází na KT 3, 4 a 9 a její výskyt se váže na stolní keramiku. Kosočtverečné vrypy se nacházejí na nádobách KT 2. V souboru zpracovaném J. Musilem se navíc objevila vlnice mezi rýhami, poměr zdobených fragmentů je v jeho souboru o něco vyšší (Musil 2013, 92-101).

Analogie $\mathrm{k}$ výzdobě s motivem kř́ižků známe $\mathrm{z}$ východních Čech například z Vízmburku, kde se tato výzdoba nachází na džbánech, pohárech či holbách v zánikovém horizontu (Koštál 2007, tab. 48). Známe ji také ze džbánu z jímky v Chrudimi, jež je datována do 15. století (Sehnoutková 2011, 138). Z východních Čech je známá také z redukčně páleného fragmentu z neznámé zaniklé vsi u Sečské přehrady (Musil 2007, 203, 216). S podobnými výzdobnými motivy se setkáme na Sionu, odkud byl získán chronologicky blízký soubor. Keramika ze Sionu vykazuje podobnosti, pokud jde o technologické znaky (převaha redukční keramiky, výskyt zakuřované) i o profilace okrajů (Jánská 1963, 239-240; 1965, 31-35).

Redukčně pálená keramika převažovala ve východních Čechách po celé 15. století (Vařeka 1998, 131; Frolík-Musil 2013, 164). Redukční zboží s příměsí slídy je typické pro čáslavský výrobní okruh definovaný J. Musilem (Musil 2010, 4-5). Analogie lze najít také u keramiky z Chrudimi - např́íklad v převaze přehnutých krajů u hrnců i ve výskytu tzv. chrudimských pohárů (Musil 2010, 1-18; Sehnoutková 2011, 62-111; Frolík-Kozáková-Musil 2018, 465; obr. 13, 

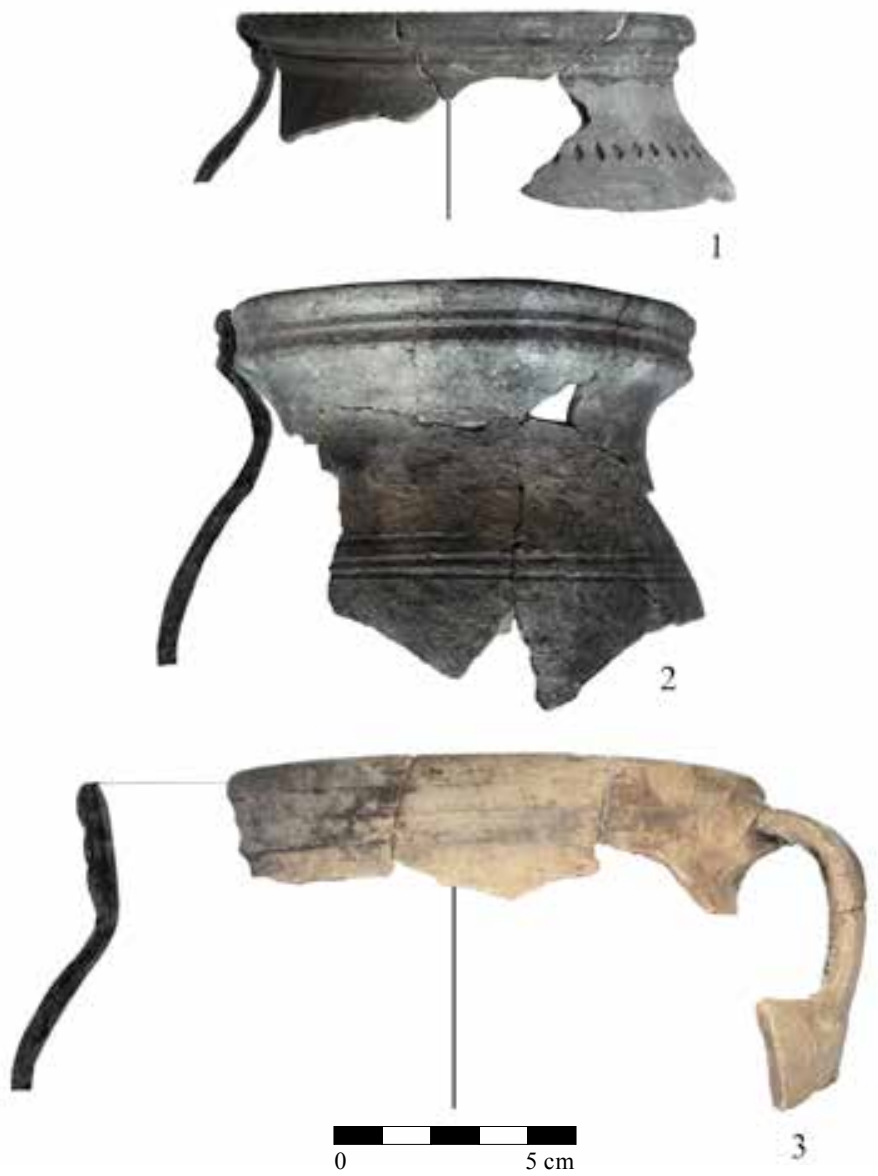

Obr. 12. Výběr z fragmentů pohárů a džbánů. Př́růstková čísla: 1 - 35-18, 35-23, 36-05 (KT 3); 2 - 35-01, 35-02, 35-03, 3504, 35-05 (KT 2); 3-35-16, 35-17, 35-19, 35-20, 35-21, 35-26 (KT 10).

Abb. 12. Auswahl an Becher- und Krugfragmenten. Akquisitionsnummern: 1 - 35-18, 35-23, 36-05 (KT 3); 2- 35-01, 35-02, 35-03, 35-04, 35-05 (KT 2); 3 - 35-16, 35-17, 35-19, 35-20, 35-21, 35-26 (KT 10).

15). Keramika datovaná do první poloviny 15 . století, která odpovídá zde zpracovanému souboru, byla nalezena na hradě Strádov (Musil-Netolický 2015, 468-469).

\section{Kuchyňská a stolní keramika - př́írodovědné analýzy}

\subsection{Metody}

Pro aplikaci př́rodovědných metod bylo vybráno 33 fragmentů (z toho 1 kachel a 4 dlaždice). Cílem bylo zodpovědět otázky týkající se rozčlenění do KT a jejich petrografických a technologických vlastností a provenience keramiky. Další otázky se týkaly speciálních vlastností, jako jsou naprríklad prŕćčina vzniku bílého jádra, určení druhu glazury či identifikace povrchové úpravy. Na základě otázek byly vybrány metody pro přírodovědné analýzy (přehled viz Čapek et al. 2018, 143-173). 


\begin{tabular}{|c|c|c|c|c|c|}
\hline Přír. č. & Mikropetrograf. & pXRF & KT & Skup. (mikropetrograf.) & Skup. (pXRF) \\
\hline $36-30$ & - & $\mathrm{x}$ & 1 & - & A \\
\hline $01-30$ & $\mathrm{x}$ & $\mathrm{x}$ & 1 & A & - \\
\hline $03-19$ & - & $\mathrm{x}$ & 1 & - & A \\
\hline $09-20$ & $\mathrm{x}$ & $\mathrm{x}$ & 1 & A & - \\
\hline $13-19$ & $\mathrm{x}$ & $\mathrm{x}$ & 1 & A & - \\
\hline $36-40$ & $\mathrm{x}$ & $\mathrm{x}$ & 1 & $\mathrm{~B}$ & - \\
\hline OP1-06 & - & $\mathrm{x}$ & 1 & - & $\mathrm{A} / \mathrm{E}$ \\
\hline $01-26$ & $\mathrm{x}$ & $\mathrm{x}$ & 2 & $\mathrm{E}$ & - \\
\hline $01-42$ & - & $\mathrm{x}$ & 2 & - & $\mathrm{A} / \mathrm{E}$ \\
\hline $09-14$ & $\mathrm{x}$ & $\mathrm{x}$ & 2 & $\mathrm{D}$ & - \\
\hline $15-04$ & $\mathrm{x}$ & $\mathrm{x}$ & 2 & A & - \\
\hline $36-51$ & - & $\mathrm{x}$ & 2 & - & $\mathrm{C}$ \\
\hline $36-52$ & - & $\mathrm{x}$ & 2 & - & A \\
\hline OP4-05 & - & $\mathrm{x}$ & 2 & - & $\mathrm{E}$ \\
\hline 08-03 & $\mathrm{x}$ & $\mathrm{x}$ & 3 & $\mathrm{C}$ & - \\
\hline $13-22$ & $\mathrm{x}$ & $\mathrm{x}$ & 3 & $\mathrm{C}$ & - \\
\hline 14-07 & $\mathrm{x}$ & $\mathrm{x}$ & 3 & $\mathrm{C}$ & - \\
\hline $36-55$ & - & $\mathrm{x}$ & 3 & - & $\mathrm{C}$ \\
\hline OP1-05 & - & $\mathrm{x}$ & 3 & - & $\mathrm{C}$ \\
\hline OP1-08 & - & $\mathrm{x}$ & 3 & - & $\mathrm{C}$ \\
\hline OP4-03 & - & $\mathrm{x}$ & 6 & - & B \\
\hline $03-23$ & $\mathrm{x}$ & $\mathrm{x}$ & 6 & B & - \\
\hline $07-13$ & - & $\mathrm{x}$ & 6 & - & $\mathrm{B}$ \\
\hline $15-05$ & - & $\mathrm{x}$ & 6 & - & B \\
\hline $19-08$ & $\mathrm{x}$ & $\mathrm{x}$ & 6 & $\mathrm{~B}$ & - \\
\hline OP1-09 & - & $\mathrm{x}$ & 6 & - & B \\
\hline $03-22$ & - & $\mathrm{x}$ & 7 & - & $\mathrm{D}$ \\
\hline 07-09 & $\mathrm{x}$ & $\mathrm{x}$ & 7 & $\mathrm{D}$ & - \\
\hline $10-11$ & $\mathrm{x}$ & - & kachel & - & - \\
\hline D1 & $\mathrm{x}$ & - & dlaždice & - & - \\
\hline D2 & $\mathrm{x}$ & - & dlaždice & - & - \\
\hline D3 & $\mathrm{x}$ & - & dlaždice & - & - \\
\hline D4 & $\mathrm{x}$ & - & dlaždice & - & - \\
\hline
\end{tabular}

Tab. 2. Seznam vzorků vybraných k př́rodovědným analýzám a jejich náležitost ke KT a mikropetrografickým skupinám. Tab. 2. Verzeichnis der für die naturwissenschaftlichen Analysen ausgewählten Proben und ihre Zugehörigkeit zu den Keramikklassen und mikropetrographischen Gruppen. 


\begin{tabular}{|c|c|c|c|c|c|c|c|c|c|c|c|c|c|c|c|c|c|c|c|}
\hline 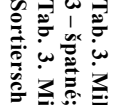 & $\underset{\perp}{\oplus}$ & $\Xi$ & 具 & $\Xi$ & $\begin{array}{l}\overrightarrow{0} \\
\stackrel{1}{=}\end{array}$ & 㐫 & $\frac{0}{1}$ & $\stackrel{1}{\stackrel{0}{0}}$ & $\begin{array}{l}\infty \\
\stackrel{\omega}{\omega} \\
\stackrel{1}{2}\end{array}$ & $\begin{array}{l}\vec{t} \\
\dot{b} \\
\dot{y}\end{array}$ & $\begin{array}{l}\bar{\omega} \\
\text { N } \\
\text { N }\end{array}$ & $\begin{array}{l}w \\
\hat{a} \\
t\end{array}$ & $\begin{array}{l}\omega \\
\text { 心 } \\
\text { N }\end{array}$ & $\begin{array}{l}\overrightarrow{0} \\
\vdots \\
\infty\end{array}$ & $\begin{array}{l}0 \\
\text { N } \\
0\end{array}$ & $\begin{array}{l}\vec{u} \\
\grave{1} \\
\dot{\phi}\end{array}$ & $\begin{array}{l}\vec{\omega} \\
\dot{\omega}\end{array}$ & $\stackrel{\vec{b}}{0}$ & Přír. č. \\
\hline 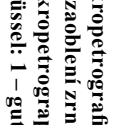 & 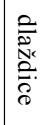 & 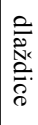 & 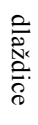 & 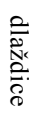 & $\begin{array}{l}\pi \\
\hat{\tilde{\Xi}} \\
\tilde{\Xi} \\
\text { है }\end{array}$ & $\pi$ & 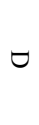 & $\theta$ & $\Omega$ & $\Omega$ & $\Omega$ & $\varpi$ & $\varpi$ & $\varpi$ & $>$ & $>$ & $>$ & $>$ & Skupina \\
\hline & $\omega$ & $\Delta$ & N & - & $\omega$ & $\omega$ & $\omega$ & - & $\omega$ & N & - & $\omega$ & N & $N$ & $\perp$ & $\omega$ & $\omega$ & $\omega$ & Kvarcit \\
\hline & 0 & 0 & 0 & 0 & 0 & 0 & 0 & 0 & - & 0 & 0 & 0 & 0 & 0 & 0 & 0 & 0 & 0 & Rula \\
\hline & 0 & 0 & 0 & 0 & 0 & - & 0 & 0 & N & 0 & N & 0 & 0 & - & 0 & 0 & 0 & 0 & Fylit \\
\hline 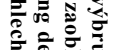 & $\omega$ & $\omega$ & - & - & 0 & $N$ & - & - & $N$ & N & $N$ & $N$ & - & - & $N$ & - & - & $N$ & Granitoid \\
\hline & un & $\omega$ & 0 & 0 & 0 & 0 & 0 & 0 & 0 & 0 & 0 & 0 & 0 & 0 & 0 & 0 & 0 & 0 & Mikrodiorit \\
\hline & 0 & 0 & 0 & 0 & - & 0 & 0 & 0 & 0 & 0 & - & - & - & 0 & - & 0 & 0 & - & Pískovec \\
\hline & $u$ & 0 & 0 & 0 & 0 & 0 & 0 & 0 & 0 & 0 & 0 & 0 & 0 & 0 & 0 & 0 & 0 & 0 & Jílovec \\
\hline હ & N & - & 0 & - & - & - & 0 & 0 & 0 & 0 & 0 & 0 & 0 & - & 0 & 0 & 0 & 0 & Silicit \\
\hline 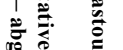 & 0 & 0 & 0 & 0 & 0 & - & 0 & 0 & 0 & 0 & 0 & 0 & 0 & 0 & 0 & 0 & 0 & 0 & Mikrit \\
\hline$\stackrel{\vdots}{ٍ}$ & 0 & 0 & $\omega$ & $\omega$ & 0 & 0 & 0 & 0 & 0 & 0 & 0 & 0 & 0 & 0 & 0 & 0 & 0 & 0 & Sklářský odpad \\
\hline $\mathbb{Z}_{\hat{X}}$ & $\triangle$ & $\Delta$ & $\omega$ & $\triangle$ & $\triangle$ & $\triangle$ & $N$ & $N$ & $\triangle$ & $u$ & ur & $\omega$ & $\omega$ & $N$ & $\omega$ & $\omega$ & $\omega$ & $\omega$ & Křemen \\
\hline$\grave{g}$ & $\omega$ & $\omega$ & N & $N$ & $N$ & - & $\perp$ & $\triangle$ & $\omega$ & $\omega$ & N & - & - & - & - & N & - & - & Alk. živce \\
\hline$\stackrel{0}{E}$ & $N$ & N & - & 0 & 0 & 0 & N & $\omega$ & $\omega$ & - & - & - & 0 & 0 & 0 & - & - & - & Plagioklasy \\
\hline 9 & - & - & N & $\omega$ & $\omega$ & $w$ & $N$ & $N$ & $N$ & $N$ & $\omega$ & $\omega$ & $N$ & $N$ & $w$ & $\omega$ & $\omega$ & $\omega$ & Muskovit \\
\hline$\approx$ & $\omega$ & $\omega$ & 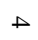 & 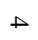 & N & $N$ & $w$ & N & N & N & N & - & - & - & $N$ & - & $N$ & N & Biotit \\
\hline$\stackrel{=}{=}$ & 0 & 0 & - & - & - & - & 0 & - & - & - & - & 0 & 0 & 0 & 0 & 0 & 0 & 0 & Amfibol \\
\hline$=$ & 0 & 0 & 0 & 0 & $N$ & - & $N$ & - & 0 & - & - & - & 0 & - & 0 & 0 & 0 & 0 & Turmalín \\
\hline$\frac{2}{2}$ & 0 & 0 & 0 & 0 & 0 & 0 & 0 & 0 & 0 & 0 & 0 & 0 & 0 & 0 & - & 0 & 0 & 0 & Allanit \\
\hline$\Xi$ & 0 & 0 & - & 0 & 0 & 0 & 0 & 0 & 0 & 0 & 0 & 0 & 0 & 0 & 0 & 0 & 0 & 0 & Sillimanit \\
\hline$=$ & 0 & 0 & $N$ & $N$ & $\omega$ & 0 & 0 & 0 & - & $N$ & - & $N$ & - & - & N & - & $N$ & - & Glaukonit \\
\hline$=$ & $\omega$ & $\omega$ & N & N & $\omega$ & $N$ & - & - & N & N & $\omega$ & - & - & - & - & - & - & - & Vytř̌idění \\
\hline ( & $N$ & N & $N$ & $N$ & $N$ & $N$ & $N$ & $N$ & $N$ & $N$ & $N$ & $N$ & $N$ & $N$ & - & $N$ & - & - & Zaoblení zrn \\
\hline$\check{\sigma}$ & N & N & $\triangle$ & $A$ & $\omega$ & $N$ & $N$ & $w$ & $u$ & un & u & $N$ & $N$ & $N$ & $\omega$ & $w$ & $w$ & $\omega$ & Aleurity \\
\hline 0 & $\omega$ & $\omega$ & N & $N$ & $\triangle$ & $\triangle$ & $\triangle$ & $\triangle$ & $w$ & $N$ & $N$ & $\omega$ & $N$ & $N$ & $\omega$ & $\omega$ & $\omega$ & $\omega$ & Psamity \\
\hline $\overrightarrow{0}$ & $\triangle$ & N & N & $N$ & 0 & 0 & 0 & 0 & 0 & 0 & 0 & 0 & 0 & 0 & 0 & 0 & 0 & 0 & Psefity \\
\hline 7 & ur & $u$ & - & 0 & 0 & - & 0 & 0 & 0 & 0 & 0 & 0 & 0 & 0 & ur & - & $\omega$ & ur & Vitrif. matrix \\
\hline
\end{tabular}




\section{Optická mikroskopie}

Podle makroskopického určení bylo vybráno třináct fragmentů keramiky (tab. 2), které posloužily pro validaci určených KT. Z těchto vzorků byly připraveny leštěné výbrusové preparáty o mocnosti $30 \mu \mathrm{m}$. Výbrusy byly pozorovány v procházejícím světle polarizačního mikroskopu Olympus BX51 a popsány dle upravené metodiky P. Quinna (2012) a M. Gregerové a kol. (2010). Mikrofotodokumentace byla provedena fotoaparátem Canon EOS 40D.

\section{Rentgen-fluorescenční spektrometrie}

K analýze chemického složení keramiky byl použit ruční rentgen-fluorescenční spektrometr (pXRF) Delta Premium. Zařízení disponuje Rh anodou s $25 \mathrm{~mm}^{2}$ křemíkovým drift detektorem. Na referenčním souboru třinácti vzorků bylo provedeno třikrát stacionární měření nábrusových ploch. Byla měřena koncentrace stopových prvků pomocí módu Lehká matrice s nastavenými $60 \mathrm{~s}$ na krok. Každé měření tedy trvalo $180 \mathrm{~s}$. Kromě referenční skupiny vzorků bylo stejným postupem změřeno ještě dalších patnáct vzorků pro validaci makroskopicky určených KT. Seznam všech analyzovaných vzorků je uveden v tabulce 2 . Změřené chemické složení bylo standardizováno podle standardních referenčních materiálů (NIST 679, GBW03101a, GBW03102a, GBW03103, Kaolin KK a Diatomaceous Soil KB).

Dalšímu statistickému zpracování byly podrobeny standardizované mediány koncentrací prvků, které jsou postiženy nepřesností měření relativně nejméně - $\mathrm{K}, \mathrm{Ca}, \mathrm{Ti}, \mathrm{V}, \mathrm{Mn}, \mathrm{Fe}, \mathrm{Rb}, \mathrm{Sr}$, Y, Zr a Pb (Hunt-Speakman 2015, 1-13). Kalibrace umožnila použít i vanad, který patří mezi lehké prvky, jejichž obsah se pomocí pXRF stanovuje obtížně. Kalibrovaná data byla podrobena analýze hlavních komponent (PCA). Tato metoda slouží ke zjednodušení popisu skupiny znaků, při které dojde $\mathrm{k}$ transformaci původních znaků na nové, nekorelované proměnné, nazvané hlavní komponenty. Každá hlavní komponenta představuje lineární kombinaci původních znaků.

\section{Rentgenová difrakce}

Prášková rentgenové difrakce (XRD) byla provedena na aparatuře Bruker D8 Advance $\mathrm{s} C u$-anodou $(\lambda \mathrm{K} \alpha=0,15418 \mathrm{~nm}), 1 \mathrm{D}$ pozičně citlivým detektorem a variabilními divergentními clonami při konvekční Bragg-Brentano parafokusační $\Theta-\Theta$ reflexní geometrii. Krok $-0,02^{\circ} 2 \Theta$, čas na krok - $188 \mathrm{~s}$, měřená úhlová oblast $-6-80^{\circ} 2 \Theta$, celková doba trvání jednoho skenu 74 min. Pro analýzu byl vybrán vzorek 1-30. Bílé jádro střepu a okolní keramická hmota byly mechanicky separovány a analyzovány zvlášt'. Po separování byly vzorky dále rozdrceny v mechanické achátové třecí misce a následně umístěny do standardních kyvet s horním plněním.

\subsection{Výsledky}

\section{Mikropetrografie keramiky}

Všechny studované vzorky je možné klasifikovat jako jemně až středně zrnitou písčitou keramiku. Neplastickou složku tvoří kromě minerálních zrn i poměrně malé množství drobných úlomků hornin (největší zjištěná frakce je písčitá). Z hornin byly zastoupeny převážně hlubinné magmatické horniny a metamorfity. Úlomky sedimentárních hornin byly zjištěny pouze sporadicky. Na základě mikrostruktury matrix, vytřídění a složení neplastické složky (tab. 3) byly vzorky rozděleny do pěti skupin (A-E).

\section{Skupina A}

Mikropetrografickou skupinu A tvoří čtyři vzorky (1-30, 13-19, 15-04 a 9-20; tab. 2). Jedná se o jemnozrnnou písčitou keramiku. Neplastickou složku tvoří převážně zaoblené úlomky kvarcitu, méně granitoidů a sporadicky zástupců sedimentárních hornin, v případě této skupiny pískovců. Mezi úlomky minerálů převažují zrna křemene a slíd (muskovit převažuje nad biotitem), v menším podílu jsou zastoupeny alkalické živce, plagioklasy a glaukonit. Mikrostruktura vzorků je paralelní, místy lentikulární. 

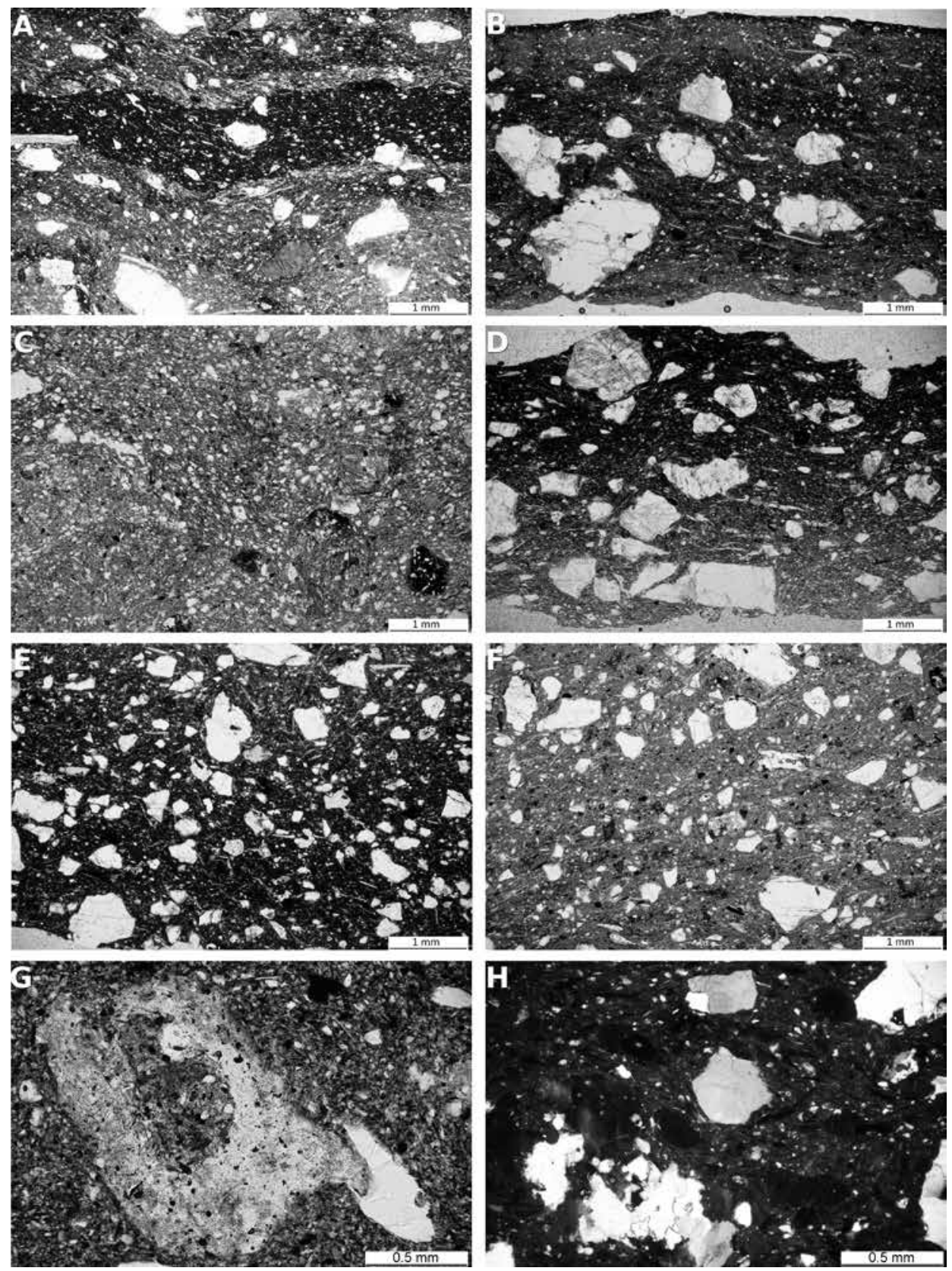

Obr. 13. Mikrofotodokumentace (v PPL). A - vitrifikované jádro vzorku 9-20 (sk. A); B - jemnozrnná matrix s písčitým ostřivem (vz. 36-40, sk. B); C - základní hmota s vysokým podílem prachovité složky (vz. 13-22, sk. C); D - částečně zaoblené až ostrohranné úlomky živců tvoř́ících ostř̌ivo vzorku 7-09 (sk. D); E - rovnoměrné zastoupení prachovitých a písčitých částic ve vz. 1-26 (sk. E); F - kromě kvarcitů tvoří neplastickou složku kachle i pískovec (vz. 10-11); G - jako ostř̌ivo u dlaždic z obléhací polohy byl použit odpad ze sklářské výroby (D1); H - dlaždice z hradu mají vlivem vysoké teploty výpalu vitrifikovanou matrix (D3). 
Abb. 13. Mikrofotodokumentation (in PPL). A - vitrifizierter Kern von Probe 9-20 (Gr. A); B - feinkörnige Matrix mit sandhaltigem Magerungsmittel (Probe 36-40, Gr. B); C - Grundmasse mit hohem Gehalt an Staubkomponenten (Probe 13-22, Gr. C); D - teilweise abgerundete bis scharfkantige Feldspatbruchstücke des Magerungsmittels von Probe 7-09 (Gr. D); E - gleichmäßiges Vorkommen von Staub- und Sandpartikeln in Probe 1-26 (Gr. E); F - neben Quarziten bildet auch Sandstein eine nicht plastische Komponente der Kachel (Probe 10-11); G - bei Fliesen von der Belagerungsstellung wurde Abfall aus der Glasproduktion als Magerungsmittel verwendet (D1); H - die Fliesen von der Burg haben durch die hohe Temperatureinwirkung des Brandes eine vitrifizierte Matrix (D3).

Charakteristická je vitrifikovaná matrix v jádře střepu (obr. 13:A). Tento jev, kdy se matrix stává opticky neaktivní, je jedním z indikátorů teploty výpalu. U běžné hrnčiny se usuzuje, že keramická matrix ztrácí optickou aktivitu při teplotách $800-850{ }^{\circ} \mathrm{C}$. Výši teploty výpalu dokládají též šupinky biotitu, které vlivem oxidace ztratily pleochroismus. Po vystavení $900{ }^{\circ} \mathrm{C}$ již biotit není pleochroický.

Odlišnost ve vzhledu matrix jádra a okrajů podnítila u vzorku 1-30, u kterého byla vitrifikace jádra nejvýraznější, provedení XRD analýzy pro srovnání jejich fázového složení (obr. 14). Bylo zjištěno, že jádro i okraj mají stejné kvalitativní fázové (minerální) složení. Jedinou výjimkou je př́tomnost minerálu se slídovou strukturou v okraji střepu. Pravděpodobně se jedná o illit, jehož př́tomnost je důsledkem kontaminace střepu při depozici. Z minerálů ostřiva je nejvíce zastoupen křemen, v menší míře byly v difrakčním záznamu identifikovány živce (jak alkalické, tak plagioklasy) a nelze vyloučit př́itomnost malého množství anatasu. $Z$ hlediska odhadu teploty výpalu je nejdůležitější přítomnost mullitu, která dokládá teplotu s jistotou přesahující $1100^{\circ} \mathrm{C}$, pravděpodobně i $1150^{\circ} \mathrm{C}$. Tomu odpovídá též přítomnost spinelu a cristobalitu. Cristobalit mohl vzniknout jednak krystalizací amorfního $\mathrm{SiO}_{2}$ vzniklého při výpalu z jílových minerálů a/nebo transformací křemene z ostřiva. Difuzní pozadí difraktogramů (tzv. ,amorfní hrb“) v oblasti ca $15-35^{\circ} 2 \Theta$ (obr. 15) dokládá př́itomnost amorfní, v tomto případě sklovité, fáze vzniklé natavením stř̌epu, které je dobře patrné i opticky ve výbrusovém preparátu. Problematický je výskyt kalcitu. Vzhledem k vysoké teplotě výpalu se může jednat pouze o sekundární minerál, který vznikl v pórech střepu při depozici. Sekundárnímu původu kalcitu odpovídá jeho relativně nízká krystalinita (na základě profilu difrakčních linií).

\section{Skupina B}

Keramika skupiny B, kterou zastupují tři vzorky (19-08, 3-23 a 36-40; tab. 2), se zrnitostí i př́ítomnými druhy hornin a minerálů skupině A podobá (obr. 13:B). Mezi úlomky hornin též převažuje kvarcit, méně jsou zastoupeny granitoidy, okrajově pískovce, silicit či metamorfit. Mezi minerálními zrny převažuje křemen. Alkalické živce jsou zastoupeny minimálně, plagioklasy ještě méně. Muskovit výskytem převažuje nad biotitem. Identifikována byla též zrna glaukonitu. Ve dvou vzorcích byl rozeznán turmalín. Vzorky mají částečně místy paralelní, místy lentikulární mikrostrukturu.

Hlavním rozdílem mezi skupinou A a B je absence vitrifikovaného jádra u vzorků skupiny B. Může se jednat pouze o technologickou rozdílnost. V tomto př́ípadě by keramická hmota mohla pocházet ze stejného zdroje, avšak nižší teplotou při výpalu nebylo dosaženo vitrifikace. Dokladem tohoto tvrzení je velmi slabě pleochroický biotit. Původní teplota výpalu byla tedy pravděpodobně okolo $900{ }^{\circ} \mathrm{C}$ nebo nižší, s ohledem na délku izotermní výdrže na nejvyšší teplotě.

\section{Skupina C}

Vzorky 8-03, 13-22 a 14-07 (tab. 2) se od vzorků předchozích skupin liší výrazně, a byly zařazeny do skupiny $\mathrm{C}$. Tuto skupinu lze popsat jako písčitou keramiku vyrobenou z hlíny s vysokým obsahem prachovité neplastické složky (obr. 13:C). Díky většímu poměru neplastické složky bylo ve výbrusech možno rozeznat větší množství horninových úlomků. Kromě kvarcitu jsou též výrazněji zastoupeny metamorfity a granitoidy. Sedimentární horniny byly zastoupeny pouze v jednom př́ípadě (pískovec ve vzorku 13-22). Mezi úlomky minerálů dominují křemenná 


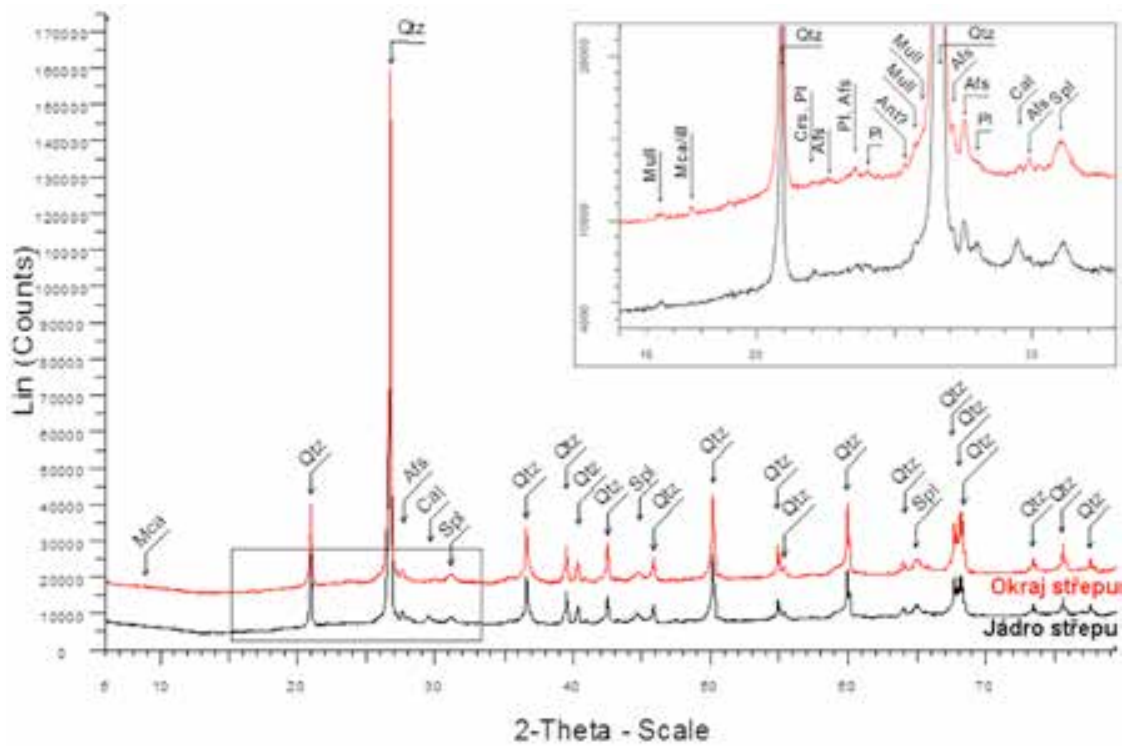

Obr. 14. Srovnání difrakčních záznamů bílého jádra a tmavého okraje střepu (vz. 1-30), vpravo nahoře detail vybrané úhlové oblasti. Qtz - křemen, Mull - mullit, Mca - slídy, ill - illit, Crs - cristobalit, Pl - plagioklasy, Afs - alkalické živce, Ant - anatas.

Abb. 14. Vergleich der diffratischen Aufnahmen des weißen Kerns und dunklen Scherbenrandes (Probe 1-30), rechts oben Detail des ausgewählten Winkelbereichs. Qtz - Quarz, Mull - Mullit, Mca - slídy, ill - Illit, Crs - Cristobalit, PI - Plagioklase, Afs - alkalische Feldspate, Ant - Anatas.

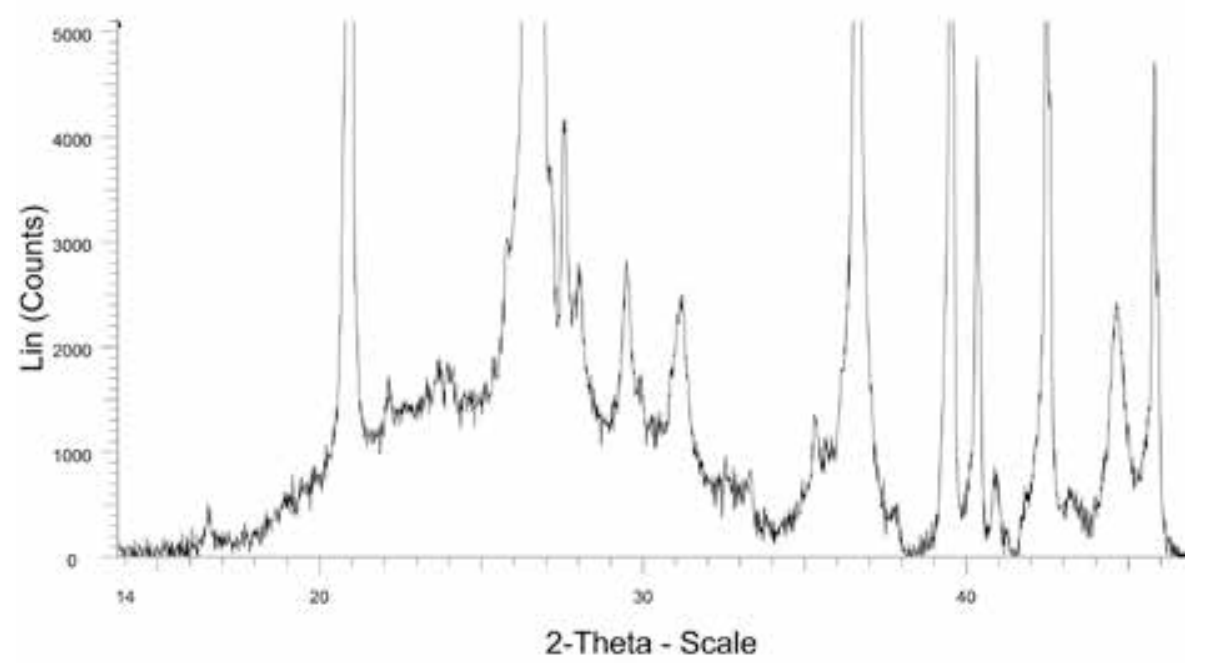

Obr. 15. Difraktogram vz. 1-30, patrný je tzv. amorfní hrb představující vysoký podíl vitrifikované složky.

Abb. 15. Diffraktogramm Probe 1-30, erkennbar ist ein sog. Amorpher Buckel, der den hohen Gehalt an vitrifizierten Komponenten darstellt. 
zrna, méně časté jsou alkalické živce, které převažovaly nad plagioklasy, a glaukonit. Muskovit $\mathrm{s}$ biotitem byly zastoupeny rovnoměrně. V malém množství byl ve všech vzorcích rozeznán amfibol a turmalín. Mikrostruktura vzorků je lentikulární.

Jediný opticky pozorovatelný znak intenzity výpalu, kterým keramika skupiny C prošla, je biotit a jeho pleochroismus. Vzorky č. 13-22 a 14-07 obsahují jak nepleochroické, tak slabě pleochroické šupinky biotitu, kdežto biotit ve vz. č. 8-03 je již nepleochroický. Teplota výpalu se pravděpodobně pohybovala $\mathrm{v}$ rozmezí $850-900^{\circ} \mathrm{C}$.

\section{Skupina D}

Skupina D byla definována na základě mikropetrografického popisu vzorků 7-09 a 9-14 (tab. 2). Pro ně je typická převaha písčité neplastické složky nad prachovitou. Zvýšené množství větších zrn, oproti předchozím skupinám, však nepřineslo větší množství úlomků hornin, které by mohly napomoci při identifikaci oblasti původu suroviny. Kromě běžně zastoupeného kvarcitu jsou minimálně zastoupeny graniotidy. Hlavní část písčité a prachovité frakce tvoří živce (obr. 13:D). Alkalické převažují nad plagioklasy. Křemen je zastoupen v menším množství. Z minerálů jsou zastoupeny i slídy, muskovit s biotitem v podobném poměru. Biotit má stále zachovaný pleochroismus. V malém množství je zastoupen amfibol a turmalín. Mikrostruktura obou vzorků je lentikulární. Pro odhad původní teploty byl stejně jako u skupiny $\mathrm{C}$ použit pouze biotit. Jeho šupinky jsou stále silně pleochroické. Teplota byla pravděpodobně v rozmezí $750-850{ }^{\circ} \mathrm{C}$.

\section{Skupina E}

Vzorek 1-26 (tab. 2) tvoří vlastní skupinu (E) a je ho možné popsat jako písčitou keramiku (obr. 13:E). Neplastickou složku tvoří úlomky kvarcitů, méně jsou zastoupeny granitoidy, minimálně pak pískovec, silicit a mikritický vápenec. Mezi minerály mají naprostou převahu zrna křemene, běžně jsou zastoupeny slídy (šupinky biotitu jsou pleochroické), živce naopak pouze okrajově, stejně tak amfibol. Tento vzorek má částečně vitrifikovanou matrix v jádře. Mikrostruktura je paralelní. Slabý pleochroismus biotitu umožňuje interpretovat původní teplotu výpalu v rozpětí $850-900{ }^{\circ} \mathrm{C}$.

\section{Provenience}

Určené mikropetrografické skupiny se vzájemně liší př́ítomností typů hornin a minerálů. Rozdíly však nejsou, vzhledem ke geologické charakteristice území, zásadní. Převažujícím typem horniny ve studovaných vzorcích jsou kvarcity a granitoidy, méně zastoupeny jsou ruly a klastické sedimentární horniny. Všechny tyto typy je možné v sedimentech řeky Doubravy očekávat. Keramika skupin A a B se charakteristikou neplastické složky podobají. Je možné uvažovat o jejich shodné provenienci. Skupina $\mathrm{C}$ se přítomnými typy hornin a minerálů od předchozích dvou zásadně neliší. Hlavní rozdíl je ve větším zastoupení prachovité složky v této keramice. Může jít o technologický znak - jiný způsob úpravy keramické hlíny (menší úprava, např. plavením, by zanechala více aplastik), nebo byla surovina získávána ze zdroje, který byl přirozeně více zrnitý. Keramika skupiny D je provenienčně nejvíce rozdílná. Velké množství relativně čerstvých (málo přeměněných) úlomkủ živců ukazuje na horniny granitoidní, př́ípadně na pegmatity. Nejbližší granitoidní horniny jsou součástí železnohorského plutonu. Pegmatity jsou naopak běžné v moldanubiku. Akcesorické minerály jako amfibol či turmalín, které v menší míře tvoří neplastickou složku, tuto domněnku potvrzují. Skupina E obsahuje úlomky pestré škály hornin, ale ani zde nebyly identifikovány horniny, které by byly pro studovanou oblast exotické. Keramická surovina byla získávána z jiného zdroje než u lokálních skupin A, B a C, avšak někde v okolí.

\section{Teplota výpalu}

Z výsledků petrografických analýz byla určena teplota výpalu u jednotlivých keramických skupin: skupina A $900-1150{ }^{\circ} \mathrm{C}$, B kolem $900{ }^{\circ} \mathrm{C}, \mathrm{C} 850-900{ }^{\circ} \mathrm{C}, \mathrm{D} 750-850{ }^{\circ} \mathrm{C}, \mathrm{E} 850-900{ }^{\circ} \mathrm{C}$. Zjištěné údaje korespondují s analýzami teplot výpalu středověké keramiky z jiných lokalit, 

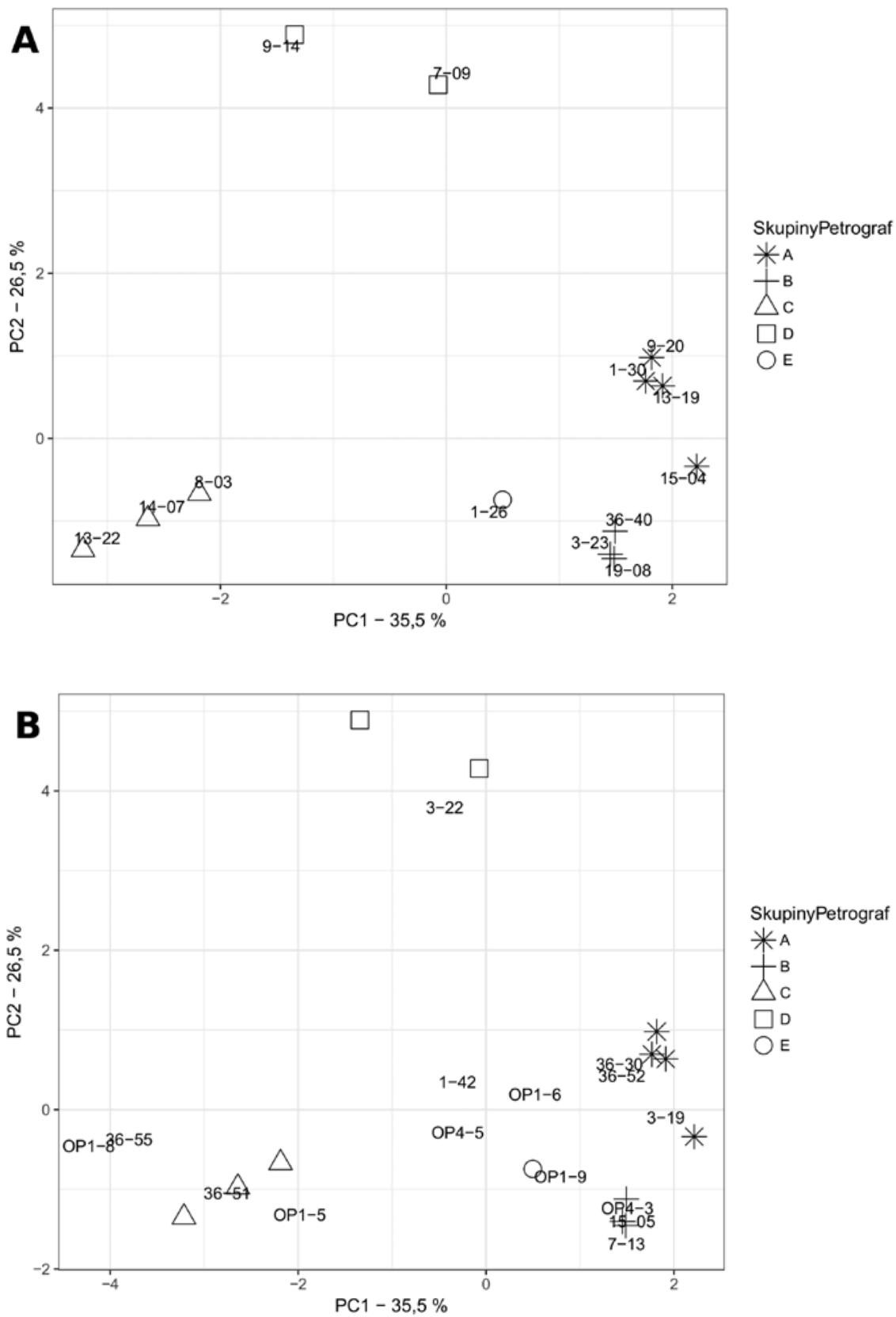

Obr. 16. Biplot první a druhé komponenty PCA analýzy zobrazující referenční vzorky (A) a všechny měřené vzorky (B). Abb. 16. Biplot der ersten und zweiten Komponente der PCA-Analyse, der die Referenzproben (A) und alle gemessenen Proben (B) darstellt. 

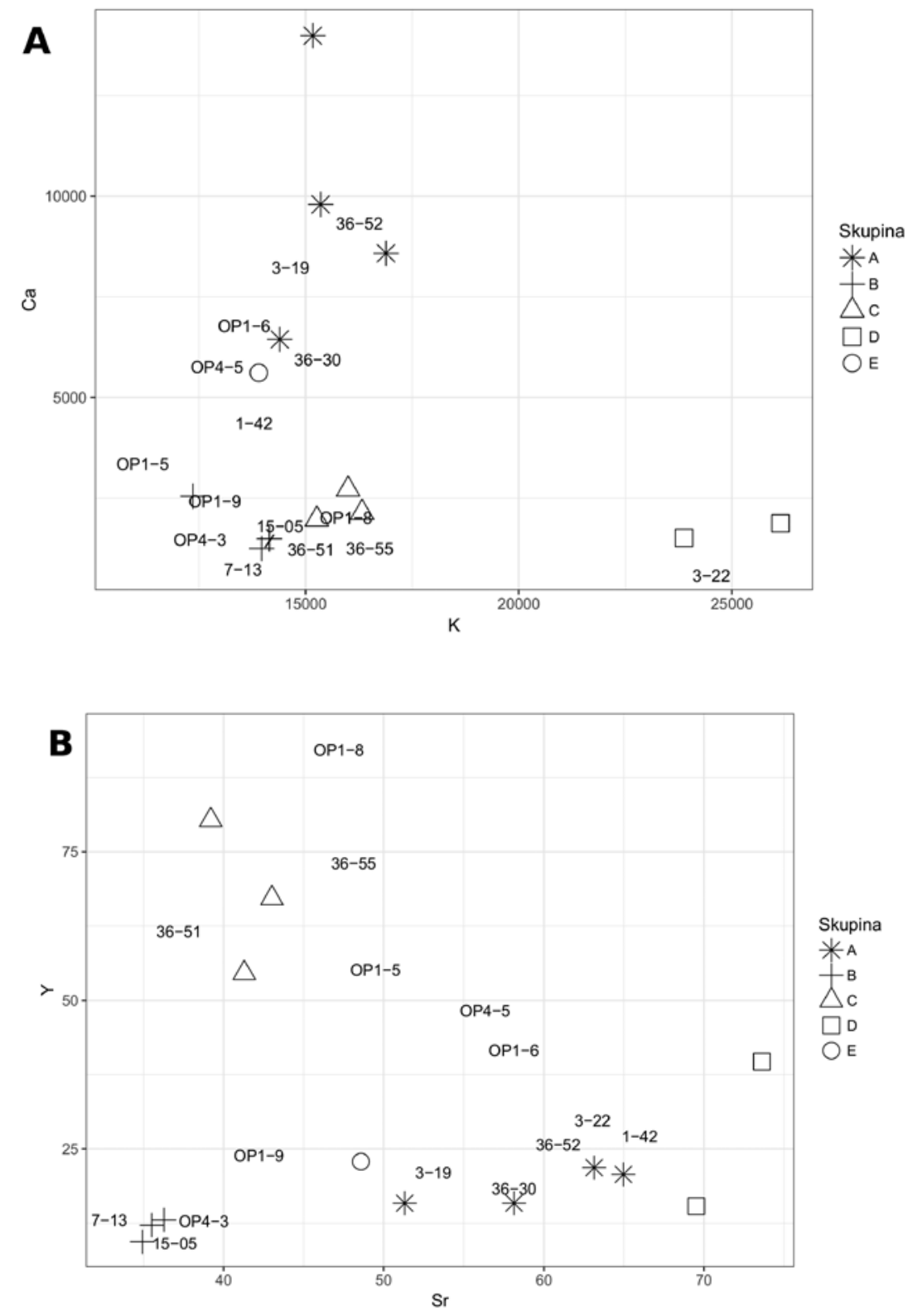

Obr. 17. Skupiny A, D a E je možné vyčlenit na základě poměru Ca a K. Vzorky skupiny A mají z celého souboru nejvyšší obsah Ca. Keramika skupiny D obsahuje největší podíl K. Skupina E je definována malým obsahem K a vyššm obsahem Ca (A). Vzájemným srovnáním obsahu Sr a Y je možné definovat všech pět referenčních skupin (B).

Abb. 17. Gruppe A, D und E können anhand des Verhältnisses von Ca und $K$ untergliedert werden. Die Proben der Gruppe A haben von der ganzen Kollektion den höchsten Gehalt an Ca. Die Keramik der Gruppe D enthält den höchsten Gehalt an K. Gruppe E wird definiert durch den geringen Gehalt an $\mathrm{K}$ und einen höheren Gehalt an $\mathrm{Ca}(\mathrm{A})$. Durch einen gemeinsamen Vergleich des Gehaltes an Sr und Y können alle fünf Referenzgruppen definiert werden (B). 
pokud pomineme skupinu A (stranou ponecháváme analýzy grafitové keramiky, u níž se obecně počítá s nižší teplotou výpalu). Pro brněnskou středověkou keramiku se uvádí teploty kolem $950{ }^{\circ} \mathrm{C}$, u keramiky z Mostu byla teplota výpalu určena mezi $900-1000{ }^{\circ} \mathrm{C}$ a vybrané vzorky keramiky z hradu Rokštejna byly páleny na teploty do $850{ }^{\circ} \mathrm{C}$ (Gregerová 1996, 178; Hanykýř Maryška-Brůček 2002, 40-52; Slavíček-Bočková-Všianský 2016, 116).

$X R F$

Prvním krokem vyhodnocení XRF měření (získané koncentrace jsou uvedeny v tabulce 4) třinácti referenčních vzorků byla PCA analýza standardizovaných výsledků. První a druhá komponenta (PC1, PC2) vyjadřují největší variabilitu v souboru - 35,5 a 26,5\%. Komponenta PC1 ilustruje vztah obsahu Ca a stopově zastoupených prvků Ti, V, Mn, Y a Zr. Komponenta PC2 je definována vztahem obsahu Fe vůči K, Rb, Sr a Pb. Samotné srovnání PC1 a PC2 pomocí biplotu (obr. 16:A) dobře reflektuje mikropetrograficky určené skupiny.

\begin{tabular}{|c|c|c|c|c|c|c|c|c|c|c|c|}
\hline Př́ír. č. & $\mathrm{K}$ & $\mathrm{Ca}$ & $\mathrm{Ti}$ & V & $\mathrm{Mn}$ & $\mathrm{Fe}$ & $\mathrm{Rb}$ & $\mathrm{Sr}$ & $\mathrm{Y}$ & $\mathrm{Zr}$ & $\mathrm{Pb}$ \\
\hline $1-26$ & 13903 & 5613 & 3773 & 76 & 281 & 19466 & 59 & 49 & 23 & 178 & 10 \\
\hline $1-30$ & 16886 & 8582 & 3085 & 30 & 161 & 21207 & 109 & 63 & 22 & 205 & 9 \\
\hline $13-19$ & 15170 & 13989 & 3048 & 40 & 217 & 20364 & 93 & 65 & 21 & 203 & 13 \\
\hline $13-22$ & 15265 & 1970 & 6414 & 135 & 156 & 16338 & 60 & 39 & 80 & 659 & 13 \\
\hline $14-07$ & 16326 & 2137 & 6080 & 103 & 175 & 16358 & 69 & 43 & 67 & 683 & 10 \\
\hline $1-42$ & 13442 & 4051 & 3319 & 149 & 306 & 23260 & 84 & 65 & 25 & 219 & 12 \\
\hline $15-04$ & 15354 & 9795 & 2916 & 13 & 157 & 15768 & 71 & 51 & 16 & 157 & 8 \\
\hline $15-05$ & 14058 & 1284 & 3232 & 30 & 114 & 18516 & 70 & 35 & 11 & 191 & 12 \\
\hline $19-08$ & 13972 & 1242 & 3207 & 42 & 95 & 19856 & 72 & 36 & 12 & 202 & 12 \\
\hline $3-19$ & 14985 & 8510 & 2959 & 26 & 148 & 16385 & 79 & 52 & 19 & 175 & 15 \\
\hline $3-22$ & 24860 & 869 & 3707 & 89 & 158 & 13092 & 174 & 65 & 32 & 280 & 28 \\
\hline $3-23$ & 14151 & 1488 & 3242 & 40 & 123 & 19020 & 69 & 35 & 9 & 199 & 12 \\
\hline $36-30$ & 14945 & 6230 & 3174 & 55 & 142 & 23271 & 105 & 59 & 20 & 225 & 28 \\
\hline $36-40$ & 12360 & 2542 & 2773 & 49 & 161 & 16702 & 55 & 36 & 13 & 141 & 28 \\
\hline $36-51$ & 15380 & 1653 & 6176 & 124 & 206 & 17179 & 69 & 38 & 64 & 602 & 17 \\
\hline $36-52$ & 15915 & 9636 & 3064 & 38 & 240 & 18191 & 86 & 60 & 24 & 186 & 10 \\
\hline $36-55$ & 15985 & 1539 & 7153 & 156 & 240 & 20141 & 83 & 47 & 71 & 682 & 22 \\
\hline 7-09 & 23874 & 1507 & 3735 & 95 & 145 & 13121 & 179 & 70 & 15 & 277 & 40 \\
\hline $7-13$ & 13878 & 1029 & 3336 & 33 & 110 & 16774 & 59 & 33 & 11 & 173 & 8 \\
\hline $8-03$ & 15998 & 2713 & 6689 & 97 & 162 & 15702 & 80 & 41 & 55 & 553 & 18 \\
\hline $9-14$ & 26137 & 1870 & 3981 & 145 & 214 & 15715 & 195 & 74 & 40 & 272 & 32 \\
\hline $9-20$ & 14395 & 6442 & 2906 & 32 & 140 & 18863 & 92 & 58 & 16 & 184 & 48 \\
\hline OP1-5 & 10828 & 3033 & 6159 & 103 & 127 & 12519 & 60 & 50 & 57 & 604 & 14 \\
\hline OP1-6 & 13907 & 6467 & 3792 & 74 & 174 & 21649 & 75 & 57 & 40 & 225 & 37 \\
\hline OP1-8 & 15606 & 1722 & 6507 & 124 & 291 & 22973 & 86 & 48 & 94 & 864 & 28 \\
\hline OP1-9 & 13192 & 2123 & 3621 & 51 & 123 & 18889 & 49 & 43 & 26 & 264 & 40 \\
\hline OP4-3 & 12877 & 1156 & 3039 & 28 & 144 & 22076 & 75 & 40 & 15 & 219 & 22 \\
\hline OP4-5 & 13249 & 6050 & 3995 & 95 & 270 & 20214 & 60 & 55 & 46 & 249 & 24 \\
\hline
\end{tabular}

Tab. 4. Standardizované zastoupení vybraných prvků získané pomocí pXRF (v ppm).

Tab. 4. Standardisiertes Vorkommen ausgewählter mithilfe pXRF gewonnener Elemente (in ppm). 
Druhým krokem bylo přiřazení patnácti měřených vzorků k petrograficky určeným skupinám na základě PCA analýzy všech měřených vzorků a koncentrací $\mathrm{K}, \mathrm{Ca}, \mathrm{Sr}$ a $\mathrm{Y}$, podle kterých jsou skupiny definovány (obr. 16:B, tab. 2). Chemicky se skupina E velice podobá skupině A, proto nebylo možné některé vzorky spolehlivě přiřadit k jedné, nebo druhé skupině (např. OP1-06, 01-42). Vzorky skupiny A mají z celého souboru nejvyšší koncentrace Ca (obr. 17:A). Skupinu B definuje nejnižší obsah Ca, K, Sr a Y (obr. 17:B). Keramika skupiny C je charakteristická nejvyšším obsahem Y a zároveň nízkým obsahem Sr. Skupinu D vyčleňují nejvyšší koncentrace K, Sr a nízké koncentrace Y. Keramika skupiny E má zvýšený obsah Ca, podobně jako skupina A.

\section{Stavební a kamnářská keramika}

Z dalších druhů keramiky byla při výzkumu objevena keramika stavební a kamnářská. Do keramiky těchto dvou kategorií spadají nálezy devatenácti fragmentů dlaždic a šestnácti fragmentů nádobkových kachlů.

\subsection{Dlaz̆dice}

Šest fragmentů dlaždic bylo nalezeno při výzkumu v roce 1968 v hloubce $1 \mathrm{~m}$, což je maximální hloubka, které sonda dosáhla. To svědčí o jejich přímé souvislosti s reliktem tzv. velitelského stanoviště. Zbytek pochází z povrchové prospekce, fragmenty byly patrně vyzvednuty a na místě zanechány detektorářem.

Dlaždice jsou dochovány velmi fragmentárně, původní rozměry nelze rekonstruovat. Výška byla mezi 4,1 až 4,3 cm. Z makroskopicky určitelných příměsí se v keramickém těstě nachází jemná slída, křemen a tmavé ostřivo obvykle do $3 \mathrm{~mm}$, ojediněle kamínky o velikosti až $1-2 \mathrm{~cm}$. Oxidačně pálené dlaždice mají na řezu rovnoměrné oranžové zbarvení svědčící o poměrně kvalitním výpalu. Nejsou zde stopy po maltovém lůžku.

Pro srovnání materiálu dlaždic z obléhací polohy a dlaždic z hradu byly jako nejvhodnější použity dlaždice z podlahy datované do 16. století, která byla odkryta při archeologickém výzkumu J. Frolíkem v roce 2004 (Matyková 2010, 18). Už na základě makroskopického pozorování bylo předběžně zhodnoceno, že se jedná o jiný materiál - vzorky se lišily strukturou keramické hmoty i barvou, dlaždice z hradu byly nižší $(3,1-3,5 \mathrm{~mm})$. K podrobné analýze bylo přistoupeno i s ohledem pokusit se určit provenienci materiálu a získat další technologické poznatky k výrobě.

\section{Mikropetrografický rozbor}

Pro mikropetrografickou analýzu byly vybrány čtyři vzorky dlaždic (tab. 3). Dvě pochází $\mathrm{z}$ obléhací polohy a dvě $\mathrm{z}$ hradu. $\mathrm{Z}$ těchto vzorků byly připraveny leštěné výbrusové preparáty a jejich vyhodnocení bylo provedeno pomocí polarizačního mikroskopu Olympus BX51 stejnou metodikou jako u keramiky stolní a kuchyňské.

Dlaždice z obléhací polohy jsou si mikropetrograficky velice podobné. Neplastickou složku tvoří písčitá a prachovitá zrna převážně křemene a slíd, v menší míře živců, glaukonitu, sillimanitu a amfibolů. Biotitu je v obou vzorcích poměrně velké množství. Úlomky hornin jsou zastoupeny v menší míře, konkrétně kvarcit, granitoidní horniny a silicit. Výše zmíněné aplastické příměsi je možné považovat - vzhledem $\mathrm{k}$ jejich zrnitostní distribuci - za přirozenou př́měs keramické hlíny. Jako ostřivo byl použit patrně odpad ze sklářské výroby (obr. 13:G). Jedná se o písčité, či jemně štěrkovité, zaoblené úlomky s natavenou matrix, ve které ,plavou“ prachovitá křemenná zrna. Samotné dlaždice byly páleny na teploty nižší než $850^{\circ} \mathrm{C}$. Většina šupinek biotitu je stále pleochroická až na málo časté oblasti s vitrifikovanou matrix. V těchto místech byla teplota výpalu vyšší než $900{ }^{\circ} \mathrm{C}$. Tyto enklávy vyšších teplot jsou však malé a málo časté. Původ suroviny pro tyto dlaždice je nutné hledat v oblasti s metamorfovanými horninami, nejblíže jsou to pararuly kutnohorsko-svratecké oblasti tvořící přímo podloží kopce Krkanka. Dále je možné 
uvažovat o provenienci v oblasti moldanubika. Charakteristické ostřivo k přesnějšímu určení provenience zatím přispět nemůže, jelikož přítomnost sklářské výroby v oblasti není pro tuto dobu potvrzena (Černá-Frýda 2010, 343).

Dva vzorky dlaždic z hradu vybrané ke srovnání jsou podstatně hrubozrnnější. Úlomky hornin a minerálů jsou až $1 \mathrm{~cm}$ velké a tvoří je mikrodiority, jílovce, kvarcity a granitoidy. V menší míře pak silicity. Mezi úlomky minerálů dominují křemeny, alkalické živce jsou v menšině, ještě méně časté jsou plagioklasy. Ze slíd je častější biotit než muskovit. Biotit je velmi silně tepelně postižen. Není pleochroický a vlivem vysoké teploty došlo k porušení původní textury šupinky se vzájemně oddělily, a to vlivem oxidace a změny objemu. Vysokou teplotu výpalu dokládá též vitrifikovaná matrix (obr. 13:H). Původní teplota výpalu přesahovala $900{ }^{\circ} \mathrm{C}$, a to po poměrně dlouhou dobu (tak aby bylo této teploty dosaženo v celém objemu dlaždice), nebo mohla být teplota daleko vyšší s dobou výdrže na maximální teplotě kratší. Přesnější stanovení teploty by bylo možné za použití XRD, která by mohla identifikovat novotvořené fáze. Magmatické horniny můžeme přisoudit původem střední části, případně kontaktu severní a střední části, železnohorského plutonu. Tato oblast tvoří více než $20 \mathrm{~km}$ dlouhý a do $5 \mathrm{~km}$ široký pruh táhnoucí se východně od Lichnice až $\mathrm{k}$ Žumberku a Skutči. V této oblasti, tvořené převážně granodiority, vystupují žíly mikrodioritů. Úlomek jílovce pravděpodobně pochází z reliktů křídových sedimentů v oblasti plutonu (například západně od Žumberka), či přímo z české křídové pánve při severovýchodní okraji plutonu.

\subsection{Kachle}

Mezi nálezy bylo identifikováno šestnáct fragmentů nádobkových kachlů ze sondy z roku 1968 (obr. 18). Nacházely se v hloubce $20-30 \mathrm{~cm}$. Je možné, že všechny fragmenty pocházejí
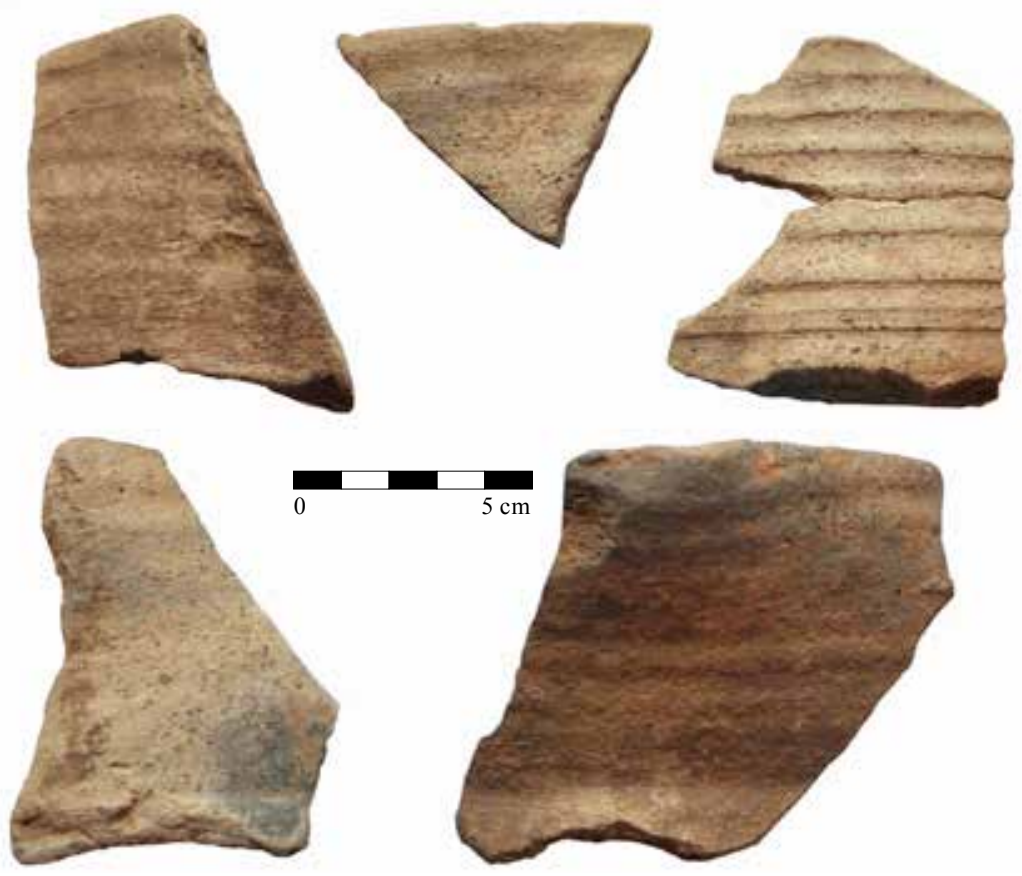

Obr. 18. Vybrané fragmenty nádobkového kachle z výzkumu V. Vokolka z roku 1968.

Abb. 18. Ausgewählte Topfkachelfragmente von der von V. Vokolek 1968 durchgeführten Grabung. 
z jednoho kachle. Původní rozměr nelze rekonstruovat. Síla stěny kachle se pohybovala od 5 do $8 \mathrm{~mm}$. Fragmenty nádobkového kachle byly získány také při prospekcích J. Musila $(2013,99)$.

Středně zrnitá hmota obsahuje jemnou slídu v obvyklém množství, nelze mluvit o tom, že by byla záměrně přidána, ale spíš byla součástí základní použité suroviny. Technologické stopy nasvědčují výrobě na rychle se točícím hrnčířském kruhu a béžová až světle šedá barva odpovídá převažujícímu oxidačnímu výpalu. Povrch je hladký, bez viditelné povrchové úpravy.

Jeden z fragmentů kachle, u kterého jsme předpokládali, že podobný typ nálezu by mohl být na lokalitu importován z větší vzdálenosti, byl vybrán pro petrografickou analýzu, a to nejen s ohledem na porovnání s běžnou hrnčířskou produkcí, ale i za účelem určení provenience.

Kachel (vz. č. 10-11) byl vyroben z poměrně zrnité keramické hlíny (obr. 13:F, tab. 3). Písčitá zrna převažují nad prachovými. Písek byl tedy pravděpodobně do suroviny přidáván jako ostřivo. Nejvíce zastoupenou horninou tvořící ostřivo je kvarcit. Ostatní horniny jsou již málo časté, jedná se o pískovec a silicit. Mezi minerály naprosto převažují křemenná zrna. Méně časté jsou alkalické živce, plagioklasy nebyly ve vzorku zastoupeny vůbec. Množství slíd nevybočuje $\mathrm{z}$ charakteristiky celého zkoumaného souboru. Muskovit je zastoupen výrazněji než biotit. Z akcesorických minerálů byly zjištěny glaukonit, turmalín a amfibol.

Původní teplota výpalu kachle byla nižší než $900^{\circ} \mathrm{C}$. Biotit již ztratil pleochroismus, avšak keramická matrix je opticky stále aktivní, není vitrifikovaná. Zjištěné úlomky hornin a minerálů tvořící neplastickou složku kachle se kvalitativně od těch, které byly určeny v keramice, významně neliší. Podle akcesorických minerálů je vyšší afinita s mikropetrografickými skupinami A, B a C. Provenienci materiálu, ze kterého byl kachel vyroben, je třeba hledat v sedimentech řeky Doubravy či jejích přítoků.

\section{Diskuze}

\subsection{Nálezová situace}

Relikty obléhacích prací v okolí hradů představují specifický typ archeologické lokality. Za jednu z hlavních výhod archeologického materiálu získaného jejich výzkumem bylo od počátku považováno to, že jej lze díky písemným pramenům o obléhání poměrně přesně datovat (Denkstein 1952; Meduna 1984, 127; podrobněji Doležalová 2013, 73-75).

Otázka osudu obléhacích areálů po splnění jejich účelu zatím nebyla uspokojivě objasněna. V př́ípadě klidného opuštění lze předpokládat, že si obléhatelé odvezli část inventáře s sebou. Je možné, že docházelo k ničení obléhacích postavení obránci, aby se předešlo jejich opětovnému využití. $V$ případě reliktu v trati Ohrada rozhodně nedošlo $\mathrm{k}$ úmyslnému zasypání příkopů tzv. velitelského stanoviště sutovým materiálem z hradu. Poboření „staveb“ v ploše nejsme schopni na základě těchto drobných výzkumů ani potvrdit, ani vyvrátit. Každopádně je nepravděpodobné, že by docházelo k výraznému zavážení reliktu sutí z hradu či vesnice (vzhledem k vzdálenosti i dostupnosti polohy), a nálezy zde učiněné lze spojit př́mo s obléháním, tak jak bylo učiněno při interpretaci výzkumů jiných obléhacích postavení v minulosti (např. Kypta-Richterová 2004, 119; Fröhlich 1991, 155-160; Jánská 1965, 31-35; Novobilský 2008, 102-103; Meduna 1994, 243-248).

Ve srovnání s nálezy z obléhacích stanovišt' u dalších hradů se zkoumaná lokalita vyznačuje poměrně významným souborem kuchyňské a stolní keramiky, který poukazuje na minimálně částečně obytný charakter místa. Málo početné keramické soubory z obdobných lokalit jsou patrně spíše důsledkem stavu výzkumu (na většině lokalit podobného charakteru nebyl proveden archeologický výzkum). Početnější nálezy keramiky známe z obléhacích poloh u hradů Lopata, Nový hrad u Kunratic, Zvíkova či Konopiště (Novobilský 2008, 102-103; Drobná 1953, 197-200; Fröhlich 1991, 158; Meduna 1994, 243-248).

Na základě nálezových okolností a rozložení KT lze předpokládat, že sonda z roku 1968 neodkryla žádnou složitější stratigrafii, což potvrzuje teorii o krátkodobém osídlení místa. Na př́slušnost nálezů $\mathrm{k}$ terénnímu reliktu také poukazuje rozložení fragmentů jednotlivých KT 
v sondě z roku 1968. Jejich výskyt $\mathrm{v}$ jednotlivých částech sondy je velmi nepravidelný a je vázán na blízkost místa s doloženými relikty zdí. Koncentrace některých keramických tříd v určitých hloubkách a vzdálenostech snad ukazuje na původní místo uložení jednotlivých kusů nádob či jejich torz (Doležalová 2013, 34). U sondy z roku 1977 bohužel neznáme podrobnější nálezové okolnosti, pro detailnější závěry by tak bylo třeba rozsáhlejšího výzkumu.

Na možnou stavební aktivitu na lokalitě vedle reliktů dvou zídek v sondě V. Vokolka upozorňují nálezy kamnářské a stavební keramiky. Na jejich základě se můžeme domnívat, že na poloze mohl existovat objekt $\mathrm{s}$ dlážděnou podlahou a že zde byla užívána kachlová kamna k jeho vytápění. Kachlová kamna známe z obléhacích postavení u hradu Lopata či Nového hradu u Adamova (Novobilský 2008, 102-103; Konečný-Merta 1980, 305-307). K nálezům keramických dlaždic prozatím analogie z našeho prostředí neznáme (jiný druh stavební keramiky prejz - známe z hradu Lopata, zde se předpokládá jeho užití v podlaze či jako součást dymníku; Novobilský 2008, 56).

Vedle obydlí se v rámci vojenských táborů předpokládají i další objekty důležité pro provoz ležení jako dílny na zpracování dřeva, kovárny, kamenické dílny, dále kuchyně a sklepy.

Z obléhacích pozic u českých hradů známe doklady kovárny u Nového hradu u Kunratic, dílny na zpracování kamene u Zbořeného Kostelce nad Sázavou či snad jakési kuchyně z Konopiště (Drobná 1953, 199; Meduna 1984, 125; 1994, 246). Pro přítomnost hrnčířské výroby v rámci těchto krátkodobých osídlení nejsou prozatím žádné archeologické ani jiné doklady.

Vzhledem k tomu, že $\mathrm{v}$ př́ípadě Lichnice jde $\mathrm{s}$ největší pravděpodobností o keramiku ze stanoviště obléhatelů hradu, je na místě otázka, odkud keramika pocházela. Část keramiky si mohli obléhatelé dovézt s sebou, ale vzhledem k poměrné křehkosti zboží si patrně část keramické výbavy obstarávali až na místě. S převážením je snad možné počítat spíš u reprezentativních, patrně picích nádob, jako jsou poháry či džbánky, které mohly být osobní výbavou jedince. Podobně jako drobnější tvary, např́íklad kahany. Zajímavé by v tomto ohledu bylo porovnání s keramikou z hradu Lichnice, její zpracování ale prozatím chybí.

Mikropetrografická analýza vybraných vzorků nepotvrdila př́tomnost importované keramiky. Importy by bylo vhodnější hledat mezi KT s nízkým výskytem na lokalitě, ty ale nebyly s ohledem na destruktivnost metod analyzovány. Všech třináct vzorkủ bylo určeno jako lokální keramická produkce. Podobně byla určena i analyzovaná stavební a kamnářská keramika.

\subsection{Porovnání keramických tř́id a výsledků petrografických analýz}

Pro ověření makroskopicky vyčleněných skupin byly vybrány vzorky početnějších KT -1 , 2, 3, 6 (po 2-4 vzorcích na KT) a jeden vzorek KT 7. Volba pouze jednoho vzorku z KT 7 souvisela s jejím vesměs makroskopicky shodným popisem a jednotnými nálezovými okolnostmi 21 fragmentů této KT, ze kterých bylo usouzeno, že se jedná patrně o fragmenty jednoho hrnce. Zajímala nás tedy odlišnost/podobnost vzhledem k ostatním KT. Ostatní KT $(4,5,8,9$ a 10) nebyly testovány $\mathrm{z}$ důvodu destruktivnosti metod - vzorků v souborech bylo totiž velmi málo. Testování, zda keramika málo početných KT byla na lokalitu importována z větší vzdálenosti, jako např́íklad oxidačně pálená keramika, by mělo být cílem budoucího výzkumu.

Již makroskopické členění poukázalo na možnou afinitu KT 1 a 6 (skupiny A, B) s odůvodněním, že skupiny jsou si velmi podobné, ale KT 1 je charakteristická poškozením povrchu postdepozičními procesy. Př́ítomnost vitrifikovaného jádra u třech vzorků KT 1 by mohlo být faktorem pro přesnější definování skupiny (skup. A), ale není možné jej ve všech případech poznat makroskopicky, a tak nelze vyloučit, že při původním popisu byla některá vitrifikovaná jádra zařazena i do KT 6 . Koncentracemi analyzovaných chemických prvků si jsou tyto dvě KT v celém souboru nejvíce podobné, proto by se mohlo zdát, že se liší pouze teplotou výpalu. Velké rozdíly ve stanoveném obsahu některých prvků (hlavně $\mathrm{Ca}, \mathrm{Sr}$ ) však dokládají, že pokud nejde o jiný zdroj suroviny, pak alespoň o rozdílnou technologii výroby (přidáním ostřiva, které změní celkové chemické složení). U těchto dvou KT by bylo vhodné provést revizi makroskopického popisu s tím, že jde o jednu KT se dvěma podskupinami. 
Nejvíce variabilní makroskopická keramická tř́ída 2 se při analýzách ukázala jako nejednotná (byla přiřazena po jednom fragmentu skupinám B, D, E) - což odpovídá i postupu při makroskopickém popisu, kdy byla tato KT vyčleněna jako poslední a byly do ní zařazeny zbývající fragmenty, pro které byl společný smíšený či převážně redukční výpal a střední zrnitost. Makroskopicky zcela nezachycena zůstala mikropetrografická skupina E.

Keramická třída 3 - skupina $\mathrm{C}$ byla vyčleněna makroskopicky i pomocí přepalování vzorků jako zcela odlišná od zbytku keramického souboru (její pojivo se při oxidačních výpalech barvilo do béžova až lehce oranžova, na rozdíl od ostatních vzorků, které byly tmavě hnědočervené). Rozdíly jsou signifikantní i při mikropetrografické charakteristice. Z hlediska chemického složení se od ostatních skupin liší koncentracemi stopových prvků ( $\mathrm{Sr}$ - nízké koncentrace, $\mathrm{Y}$ a $\mathrm{Zr}$ - vysoké koncentrace).

Fragmenty KT 7 (̌̌. vz. 03-22 a 07-09), která byla v souboru zastoupena fragmenty jednoho hrnce, se ukázaly jako podobné jednomu z fragmentů KT 2 (č. vz. 09-14) - mikropetrografická skupina D. Nalezení makroskopického znaku pro tuto skupinu by mohly pomoci pouze analýzy dalších fragmentů stejné skupiny. Zjednodušeně je tak možné KT 7 zařadit jako další podskupinu KT 2, u které by bylo třeba provést detailnější analýzu. Podrobnější a efektivnější makroskopické členění by bylo jednodušší, kdyby byl keramický soubor početnější.

Z pěti testovaných KT byla u čtyř (1, 3, 6 a 7) potvrzena správnost jejich makroskopického vyčlenění. Poslední testovaná KT 2 byla vyhodnocena jako vysoce různorodá a bylo by $\mathrm{k}$ ní možné přiřadit i poslední KT testovatelnou pouze $\mathrm{v}$ jednom vzorku - zde je potřeba hledat další možnosti makroskopického třídění. Vyčleněné makroskopické skupiny každopádně poměrně korespondují s výsledky mikropetrografického rozboru a ukazují na možné provázání obou metod. To by mělo probíhat v průběhu zpracování souboru a při diskuzi archeologa a petrografa.

Zde vyčleněné makroskopické KT, vytvořené na základním vzorku (do 500 fragmentů) a upravené pomocí petrografických skupin, lze považovat za dobrý základ pro efektivní zpracování další keramiky z lokality a jejího okolí. Další zpracování by vedle archeologie mělo opět zahrnout aplikaci přírodovědných analýz s cílem neustálé konfrontace, ověřování a získávání dalších poznatků.

\section{Závěr}

Celkem bylo zpracováno 437 fragmentů kuchyňské a stolní keramiky - 277 ze sondy V. Vokolka z roku 1968, 133 ze sondy P. Rouse z roku 1977 a 27 z povrchové prospekce z roku 2012. Vzhledem k vysoké fragmentarizaci souboru byla větší pozornost věnována složení keramického těsta a technologii výroby.

Keramický soubor z trati Ohrada můžeme datovat do první poloviny 15. století, patrně jej lze spojit s obléháním hradu v letech 1428-1429. Jiný soubor ze stejné lokality byl zpracován již dříve a byl určen jako typický pro první polovinu 15. století na Chrudimsku (Musil 2013, 164-166). Situace odkrytá v sondě provedené V. Vokolkem v roce 1968 včetně rozmístění keramických fragmentů nasvědčuje krátkodobému osídlení lokality.

Z keramických tvarů v souboru převažují hrnce, dále se objevily fragmenty pokliček, kahanů, džbánů, pohárů či misek. Okraje hrnců jsou nejčastěji přehnuté. Keramika je zdobená žlábky, vrypy či radélkovou výzdobou. Nejčastější př́iměsí je jemnozrnný či stř̌edně zrnitý křemenný písek. V souboru dominuje redukčně pálená keramika vyráběná na rychle rotujícím kruhu. Z povrchových úprav se zde vyskytuje keramika leštěná, poslídovaná a jeden fragment keramiky glazované. Č́st fragmentů má vrchní vrstvu setřenou či poškozenou působením transformačních procesů.

$\mathrm{V}$ rámci souboru bylo rozpoznáno deset keramických tříd. Pět z nich, vyskytujících se ve vyšším počtu než 20 fragmentů, bylo vybráno k ověření a určení technologických vlastností a provenience pomocí mikropetrografie. Výsledky byly ověřeny pomocí pXRF. 
Rozšířený popis technologických znaků použitý při definování KT se ukázal jako poměrně úspěšný a z pěti ověřovaných byla potvrzena správnost vyčlenění u čtyř KT. Pátá skupina zjištěná petrograficky jako velice různorodá byla takto označena už při makroskopickém vyčlenění.

Mikropetrografický popis odhalil zajímavý technologický znak u jedné z popisovaných skupin (A), a to vitrifikovanou část keramické matrix. V souboru se u některých šedě zbarvených fragmentů jeví jako bílé jádro (u kompletně oxidačně pálené keramiky je vitrifikovaná matrix stejně zbarvená jako okolní část keramické hmoty). Nepodařilo se jednoznačně určit žádné importy. Jako nejpravděpodobnější se jeví hypotéza, že všechny zkoumané vzorky byly vyrobeny v regionu blízkém zkoumané lokalitě. Interpretace původní teploty výpalu odpovídá předpokladům pro technologické možnosti středověkého hrnčíře první poloviny 15. století. Analýzy chemického složení měřením nábrusových ploch pomocí pXRF potvrdily mikropetrograficky vyčleněné skupiny a pomohly $\mathrm{k}$ těmto třídám přičlenit další fragmenty.

Vedle kuchyňské a stolní keramiky se studie věnuje nálezům keramiky kamnářské a stavební, které nejsou pro lokalitu tohoto typu zcela běžné. Nálezové situace fragmentů kachlů a dlaždic v sondě z roku 1968 ukazují na jejich souvislost s objektem tzv. velitelského tábora. Lze tak uvažovat o existenci dlážděného prostoru či kachlových kamen v jeho prostoru. Analyzované fragmenty dlaždic i kachlů byly určeny jako lokální produkce, technologicky zajímavé je pravděpodobné využití odpadu ze sklářské výroby jako ostřiva v dlaždicích.

Děkujeme doc. RNDr. Miroslavě Gregerové, CSc., za konzultace při mikropetrografické analýze keramiky. 


\section{Seznam keramických tříd}

\section{Keramická třída 1 - hrubá šedá}

1. křemen, středozrnná $(0,5-1,5 \mathrm{~mm})$, přirozená prŕíměs slídy

2. často hrubý s vystupujícími zrny křemene $\mathrm{z}$ jedné nebo obou stran (hladší v případě,

že na vnější či vnitřní straně jsou dochovány zbytky povrchové úpravy či původního povrchu), bez úpravy povrchu, vytáčená

3. středně tvrdý, zakuřování, objevují se bílá jádra

4. krémová až světle šedá, při dochované původní povrchové vrstvě středně až tmavě šedá, jádro krémová až světle šedá, u bílých jader bílá barva

5. KT 5, KT6 - patrně jde zčásti o tytéž, ale u KT 5 poslídování a u KT 6 je dochován z obou stran původní povrch střepu, KT 1 má původní povrch z velké části setřený

6. 133 fragmentů; hrnce, kahan, miska, poklička

\section{Keramická třída 2 - drolivá}

1. křemen, středozrnná $(0,5-1,5 \mathrm{~mm})$, přirozená př́íměs slídy, drolivá struktura

2. převažuje jemně drsný povrch, v některých príípadech hladký, bez úpravy povrchu, vytáčená na rychle rotujícím kruhu

3. ne př́liš kvalitní často měkký, smíšený či redukční, v několika př́ípadech známky oxidačního přežahu, často černé jádro s nevyhořelou organikou

4. odstíny hnědošedé až hnědé

6. 79 fragmentů; hrnce, pokličky, džbán, kahan, miska

\section{Keramická třída 3 - leštěná}

1. jemnozrnná $(0,1-0,5 \mathrm{~mm})$, jemný písek a přirozená př́íměs slídy, kompaktní struktura

2. velmi hladký, příp. hladký, leštění v horizontálních čí mírně šikmých užších či širších pásech, vytáčená na rychle rotujícím kruhu

3. středně tvrdý - kvalitní, zakuřování

4. převažuje středně až tmavě šedá na povrchu, světle šedá až béžová $v$ jádru

6. 65 fragmentů; hrnce, pohár, poklička

\section{Keramická třída 4 - slídová}

1. středozrnná $(0,5-1,5 \mathrm{~mm})$, střední až velké množství slídy - zrníčka (kolem $1 \mathrm{~mm})$ nebo šupinky (kolem $2 \mathrm{~mm}$ ), písek

2. hladký až jemně drsný, vytáčená na rychle rotujícím kruhu

3. středně tvrdý nebo měkký, redukční i oxidační

4. široká škála barev (od šedých přes hnědé až k okrové, červené)

6. 13 fragmentů; hrnec, kahan, poklička

\section{Keramická třída 5 - poslídovaná}

1. středozrnná $(0,5-1,5 \mathrm{~mm})$, méně často jemnozrnná $(0,1-0,5 \mathrm{~mm})$, písek, slída na povrchu, v keramickém těstě v malém množství

2. hladký až jemně drsný, poslídování z vnější strany nebo z obou stran, vytáčená na rychle rotujícím kruhu

3. převažuje středně tvrdý, redukční, ojediněle smíšený

4. středně až tmavě šedá, na lomu světle až středně šedá

5. KT1 - část fragmentů KT1 je poslídovaná, třídy se liší poškozením povrchu fragmentů

u KT1

6. 19 ; hrnce

\section{Keramická tř́ída 6 - tmavá šedá}

1. písčité ostřivo - patrně křemen, přirozená př́íměs slídy, středozrnná $(0,5-1,5 \mathrm{~mm})$, méně často jemnozrnná $(0,1-0,5 \mathrm{~mm})$

2. převážně hladký nebo jemně drsný, vytáčená na rychle rotujícím kruhu

3. středně tvrdý, redukční, může se objevit oxidační přežah

4. tmavě šedá až středně šedá, na lomu někdy o něco světlejší

5. KT1 - část fragmentů KT1 má zbytky tmavě šedého povrchu, tř́ídy se liší poškozením povrchu fragmentů u KT1

6. 93 fragmentů; hrnce, poklice, kahan, pohár 


\section{Keramická třída 7 - hrubá hnědá}

1. křemen, středozrnná $(0,5-1,5 \mathrm{~mm})$, přirozená příměs slídy

2. krupičkovitý - s vystupujícími zrny křemene obvykle z obou stran (vzniklý poškozením povrchu fragmentů postdepozičními procesy), vytáčená na rychle rotujícím kruhu

3. měkký až středně tvrdý, redukční až smíšený

4. tmavě až středně hnědá

6. 21 fragmentů; hrnec

\section{Keramická tř́ída 8 - glazovaná}

1. písčité ostřivo, středozrnná $(0,5-1,5 \mathrm{~mm})$, přirozená př́íměs slídy

2. hladký, glazura z vnitřní strany, z vnější přesah na okraj, částečně setřelá

3. středně tvrdý, redukční

4. barva stř̌epu světle šedá až šedohnědá, barva glazury tmavě zelená (Munssell 5GY 3/2)

6. 1 fragment

\section{Keramická třída 9 - oxidační červená}

1. středozrnná $(0,5-1,5 \mathrm{~mm})$ - písek, přirozená příměs slídy

2. hladký až krupičkovitý, bez povrchové úpravy

3. měkký, oxidační

4. okrová až červená

6. 2 fragmenty; snad pohár/džbán

\section{Keramická tř́ída 10 - oxidační světlá}

1. jemnozrnná $(0,1-0,5 \mathrm{~mm})$, přirozená příměs slídy, jemné písčité ostřivo v malém množství

2. hladký, bez povrchové úpravy

3. středně tvrdý, oxidační

4. béžová

6. 11 fragmentů; džbán

Př́loha č. 1. Seznam keramických tř́íd. Popis: 1 -hlína, 2 - povrch, 3 -výpal, 4 -barva, 5 -afinita s jinou keramickou tř́ídou (podle Nováček 2000, 39). Jako bod 6 je zde přidána stručná keramická náplň skupiny. Fotodokumentace viz Doležalová 2013, obr. 63-72.

Anhang Nr. 1. Verzeichnis der Keramikklassen. Beschreibung: 1 - Lehm, 2 - Oberfläche, 3 - Brand, 4 - Farbe, 5 - Affinität mit einer anderen Keramikklasse (nach Nováček 2000, 39). Als Punkt 6 wurde hier ein knapper Keramikgehalt der Gruppe hinzugefügt. Fotodokumentation siehe Doležalová 2013, Abb. 63-72. 
111)199199 97919919a9 T19a1)7199 19a1) 1991991 (1) 
Příspěvek vznikl v rámci projektu NAKI II „Vrcholně středověká keramika jako součást movitého kulturního dědictví“ č. DG18P02OVV020.

\section{Prameny vydané}

HLAVÁČEK, I. et al., 1981: Ze zpráv a kronik doby husitské. Praha.

FRB II: Fontes rerum bohemicarum, series nova, tomus II. (Černá, A. M.-Čornej, P.-Klosová, P., edd.). Praha 2003.

FRB V: Fontes rerum bohemicarum, tomus V. (Emler, J., ed.). Praha 1893.

PORÁK, J.-KAŠPAR, J., 1980: Ze starých letopisů českých. Praha.

\section{Literatura}

ABBINK, A. A., 1999: Make and Break it: the cycles of pottery. Leiden.

ALLAN, J.-LANGMAN, G., 2002: A group of medieval pottery from Haycroft Farm, Membury, Proceedings of the Devon Archaeological Society 60, 59-73.

ČAPEK, L. a kol., 2018: Čapek, L.-Těsnohlídková, K.-Slavíček, K.-Všianský, D.-Pracný, P., Technologie výroby a archeometrické studium středověké keramiky. Plzeň - Brno.

ČERNÁ, E.-FRÝDA, F., 2010: Sklo vrcholného středověku - současný stav a perspektivy studia historických technologií - Das Glas des Hochmittelalters - gegenwärtiger Stand und Perspektiven des Studiums historischer Technologien, AH 35, 335-357.

DASZKIEWICZ, M., 1998: Die mittelalterliche Keramik von Plock (Polen) als Beispiel für die Anwendungsmöglichkeiten physikalischer und chemischer Untersuchungen auf Massenfunde. In: Internationale Tagungen in Mikulčice (Poláček, L., ed.), 257-273. Brno.

DASZKIEWICZ, M.-BARANOWSKI, M., 2011: The Potential of Macroscopic Identification of Laboratory-defined Provenance Group. The Case of So-called Pergamenian Sigillata from Delos, Greece, Études et Travaux 24, 41-65.

DASZKIEWICZ, M.-SCHNEIDER, G., 2011: Laboratory Analysis of So-called Pergamenian Sigillata from Delos, Greece, Études et Travaux 24, 78-93.

DOLEŽALOVÁ, K., 2013: Vyhodnocení archeologických nálezů z areálu obléhacího stanoviště v trati Ohrada u hradu Lichnice. Rkp. magisterské diplomové práce, ulož. na ÚAM FF MU, Brno. Dostupné z: https://bit.ly/2EzjLKP.

DENKSTEIN, V., 1952: O archeologický výzkum husitských lokalit, ČNM 120, 107-115.

DROBNÁ, Z., 1953: Husitský polní tábor u Kunratic, Historie a vojenství 2, 197-200.

DURDÍK, T., 2009: Ilustrovaná encyklopedie českých hradů. Praha.

EL OUHABI, M.-DAOUDI, L.-HATERT, F.-FAGEL, N., 2015: Modified mineral phases during clay ceramic firing, Clays and Clay Minerals 63, č. 5, 404-413. https://doi.org/10.1346/CCMN.2015.0630506

FROLÍK, J., 2002: Militaria, nálezy z obléhání hradu Lichnice v letech 1428-1429, CB 8, 399-408.

FROLÍK, J.-KOZÁKOVÁ, R.-MUSIL, J., 2018: Jímka 938 z Chrudimi - Hradební ulice. Pokus o určení statutu jejího majitele - Abwassergrube 938 in Chrudim - Hradební-Straße: Versuch einer Statusbestimmung ihres Besitzers, AH 43, 455-489.

FROLÍK, J.-MUSIL, J., 2013: Několik poznámek k obléhání hradu Lichnice v letech 1428-1429, Chrudimský vlastivědný sborník 17, 125-214.

FRÖHLICH, J., 1991: Středověká opevnění kolem hradu Zvíkova, CB 2, 155-160.

GREGEROVÁ, M., 1996: Petrografické rozbory středověké brněnské keramiky, Geologické výzkumy na Moravě a ve Slezsku za rok 1995, 178-179.

GREGEROVÁ, M. a kol., 2010: Petroarcheologie keramiky v historické minulosti Moravy a Slezska. Brno.

HANYKÝŘ, V.-MARYŠKA, M.-BRU゚ČEK, P., 2002: Hodnocení mikrostruktury a fázového složení keramiky z Mostu. In: Archeologie středověkého domu v Mostě (čp. 226). Mediaevalia archaeologica 4 (Klápště, J., ed.), 35-76. Praha - Most.

HOFER, N. et al., 2010: Handbuch zur Terminologie der mittelaterlichen und neuzeitlichen Keramik in Österreich. Wien.

HORÁK, F.-CHRAMOSTA, E., 1923: Cesta Liběcká v dějinných proměnách se stezkami vedlejšími a strážnicemi. Praha.

HUNT, M. W. A.-SPEAKMAN, R. J., 2015: Portable XRF analysis of archaeological sediments and ceramics, Journal of Archaeological Science 53, 1-13.

JÁNSKÁ, E., 1963: Archeologický výzkum hradu Sión, AR XV, 220-247. 
- 1965: Hrad Jana Roháče z Dubé Sion, Sborník Oblastního muzea v Kutné Hoře 6-7, řada A, 5-72.

JOHNSON, J. S. et al., 1988: Johnson, J. S.-Clark, J.-Miller, A. S.-Robins, D.-Schiffer, M. B.-Skibo, J. M., Effects of Firing Temperature on the Fate of Naturally Occuring Organic Matter in Clays, Journal of Archaeological Science 15, 403-414. https://doi.org/10.1016/0305-4403(88)90038-6

KALTENBERGER, A., 2009: Keramik. Des Mittelalters und der Neuzeit in Oberösterreich. Band I: Grundlagen. Linz.

KLAUS, A., 1898: Lichnice. Kutná Hora.

KONEČNÝ, L.-MERTA, J., 1980: Pokračování průzkumu středověkých opevnění kolem Nového hradu u Adamova - Die Fortsetzung der Erkundungen mittelalterlicher Befestigungen um Nový hrad bei Adamov, AH 5, 305-319.

KOŠŤÁL, J., 2007: Archeologické nálezy z hradu Vízmburku. Rkp. magisterské diplomové práce, ulož. na ÚAM FF MU, Brno.

KYPTA, J.-RICHTEROVÁ, J., 2004: Tábor obléhatelů z doby husitských válek u Bechyně. In: Dějiny staveb. Sborník př́íspěvků z konference Dějiny staveb 2003, 117-122. Plzeň.

MATĚJKOVÁ, K., 2014: Keramický sortiment turnovských domácností. Možnosti zpracování keramických souborů z městských souvrství - Das Keramiksortiment aus den Turnauer Haushalten: Bearbeitungsmöglichkeiten der aus Stadtschichten stammenden Keramikkollektionen, AH 39, 89-118.

MATYKOVÁ, I., 2010: Historie hradu Lichnice v Železných horách. Třemošnice.

MAZÁČKOVÁ, J., 2012: Militária z hradu Rokštejna v širším středoevropském kontextu. Rkp. disertační práce, ulož. na ÚAM FF MU, Brno.

MEDUNA, P., 1984: Pozůstatky středověké militární činnosti u hradu Kostelce nad Sázavou, Sborník vlastivědných prací z Podblanicka 25, 119-128.

- 1994: Povrchový průzkum komplexu obléhacích prací u Konopiště 1467-1468, CB 4, 243-250.

MUSIL, J., 2007: Neznámá zaniklá středověká vesnice pod Sečskou přehradou (k. ú. Seč a k. ú. Hoješín, okr. Chrudim, ZMHK 33, 199-219.

- 2010: Pozdně středověký a raně novověký soubor keramiky z Chrudimi. Příspěvek k poznání nastupující novověké keramické produkce, Východočeský sborník historický 17, 1-18.

- 2013: Soubor keramiky z velitelského stanoviště pod hradem Lichnicí (k. ú. Podhradí v Železných horách, okr. Chrudim), AVČ 5, 87-111.

MUSIL, J.-NETOLICKÝ, P., 2015: Dokumentace reliktů předhradí hradu Strádova (okres Chrudim) - Dokumentation der Relikte der Vorburg von der Burgruine Strádov (Bezirk Chrudim), AH 40, 457-473.

NOVÁČEK, K., 2000: Středověký dům v Plzni. Archeologický výzkum parcely v Sedláčkově ulici 1, Sborník Západočeského muzea v Plzni, řada historie 15, 5-66.

NOVÁČEK, K. et al., 2010: Kladrubský klášter 1115-1421. Osídlení - architektura - artefakty. Plzeň.

NOVOBILSKÝ, M., 2008: Obléhání hradu Lopaty. Plzeň.

ORTON, C.-HUGHES, M., 2013: Pottery in Archaelogy. Second edition. Cambridge.

ORTON, C.-TYERS, P.-VINCE, A., 1993: Pottery in Archaeology. Cambridge.

PROCHÁZKA, R., 2007: Deskripční systém brněnské keramiky, PV 48, 234-270.

QUINN, P., 2012: Ceramic Petrography - The Interpretation of Archaeological Pottery and Related Artefacts in Thin Section. Oxford.

ROUX, V., 2011: Antropological interpretation of ceramic assemblages: foundations and implementations of technological analysis. In: Archaeological Ceramics: A Review of Current Research (Scarcella, S., ed.), 80-88. Oxford.

- 2017: Ceramic manufacture: The chaine opératorie Approach. In: The Oxford Handbook of Archaeological Ceramic Analysis (Hunt, A., ed.), 101-113. Oxford.

SEDLÁČEK, A., 1900: Hrady, zámky a tvrze království Českého. Díl 12. Čáslavsko. Praha.

SEHNOUTKOVÁ, P., 2011: Chrudim, Filištínská ulice čp. 39/I, odpadní jímky XIXA, XIXB a XX (příspěvek k poznání hmotné kultury). Rkp. magisterské diplomové práce, ulož. v ÚAM FF MU, Brno.

SLAVÍČEK, K.-BOČKOVÁ, Z.-VŠIANSKÝ, D., 2016: Analýzy keramických materiálů z hradu Rokštejna. In: Workshopy ke středověké a novověké keramice, Panská Lhota 2015 (Doležalová, K.-Měřínský, Z.Klápště, J., edd.), 110-118. Brno.

TEPLÝ, J., 2005: Obležení hradu Lichnice 1428-1429. Dnešní stav stop po obléhacím okruhu. In: Husitský Tábor. Jan Žižka z Trocnova a husitské vojenství v evropských dějinách (Drda, M.-Vybíral, Z., edd.), 463-475. Tábor.

VAŘEKA, P., 1998: Prameny keramické produkce vrcholného a pozdního stř̌edověku v Čechách, AR L, $123-137$.

ZELENKA, P., 2005: Křídové sedimenty na území listu 23-221 Ždírec nad Doubravou, Zprávy o geologických výzkumech v roce 2004, 55 . 
Geologická mapa 1:50 000 online České geologické služby. Dostupné z: https://mapy.geology.cz/geocr50/, cit. 5. 12. 2018.

\section{Zusammenfassung}

\section{Die Keramikkollektion von der Lage Ohrada bei Burg Lichnice}

Der vorliegende Beitrag beschäftigt sich mit der Bearbeitung der von der Belagerungsstellung in der Lage Ohrada bei Burg Lichnice (Bezirk Chrudim) stammenden Keramikfunde. Insgesamt wurden 437 Fragmente von Küchen- und Tafelkeramik bearbeitet. Die Keramikfragmente stammen von drei archäologischen Grabungen - in zwei Fällen handelte es sich dabei um Sondiergrabungen (aus dem Jahren 1968 und 1977), im dritten um eine Oberflächenprospektion. Im Hinblick auf die hohe Fragmentisierung der Kollektion wurde der Zusammensetzung der Keramikmasse und dem Herstellungsverfahren eine größere Aufmerksamkeit gewidmet.

Die Keramikkollektion von der Lage Ohrada können wir in die erste Hälfte des 15. Jahrhunderts datieren, offenbar kann sie mit der in den Jahren 1428-1429 erfolgten Belagerung der Burg in Verbindung gebracht werden. Die durch die Sondiergrabung von 1968 freigelegte Situation deutet zusammen mit der Verteilung der Keramikfragmente auf eine kurzfristige Besiedelung der Fundstelle hin.

Von den in der Kollektion enthaltenen Keramikformen überwiegen Töpfe, ferner kamen Fragmente von Deckeln, Öllämpchen, Krügen, Bechern oder Schüsseln vor. Die Topfränder sind am häufigsten umgebogen. Die Verzierung der Keramik bestand aus Rillen, Einritzungen oder Rädchenverzierungen. Die häufigste Beimischung ist feinkörniger oder mittelkörniger Quarzsand. In der Kollektion dominiert auf einer schnell drehenden Töpferscheibe gedrehte und im Reduktionsbrand gebrannte Keramik. Von den Oberflächenbehandlungen kommt polierte, mit Glimmer versehene Keramik vor, und ein Keramikfragment war glasiert. Bei einem Teil der Fragmente war die oberste Schicht verwischt oder völlig durch die Einwirkung von Transformationsprozessen beschädigt.

Im Rahmen der Kollektion wurden zehn Keramikklassen unterschieden. Fünf von ihnen, die mit über 20 Fragmenten vertreten waren, wurden zur Überprüfung und Bestimmung der technologischen Eigenschaften und der Provenienz mittels Mikropetrographie ausgewählt. Die Ergebnisse wurden mittels pXRF überprüft.

Die bei der Definierung der Keramikklassen herangezogene erweiterte Beschreibung der technologischen Merkmale erwies sich als relativ erfolgreich, und von den fünf überprüften Gruppen wurde bei vier Klassen die Richtigkeit der Untergliederung bestätigt. Die fünfte, petrographisch als sehr inhomogen bestimmte Gruppe war bereits bei der makroskopischen Untergliederung als solche bezeichnet worden. Die von der Probengrundlage (bis 500 Fragmente) gebildeten und anhand der petrographischen Gruppen untergliederten makroskopischen Klassen können so als gute Grundlage für eine effiziente Bearbeitung weiterer von der Fundstelle und ihrer Umgebung stammender Keramik angesehen werden.

Die gesamte Keramik wurde als lokale Produktion bestimmt, deren Keramiklehmressourcen aus der Umgebung der Burg stammen. Die Brenntemperatur der Keramik bewegte sich in den Intervallen zwischen $750-850{ }^{\circ} \mathrm{C}$ bis $900-1150{ }^{\circ} \mathrm{C}$. Bei über $900{ }^{\circ} \mathrm{C}$ gebrannter Keramik wies der Scherben einen vitrifizierten Kern auf.

Neben Küchen- und Tafelkeramik widmet sich die Studie auch Funden von Ofen- und Baukeramik, die für eine Fundstelle dieses Typs nicht ganz üblich sind. Die Fundsituation bzgl. Kachel- und Fliesenkeramik von der Sondiergrabung aus dem Jahr 1968 deutet auf ihren Zusammenhang mit dem Objekt eines sog. Kommandolagers hin. Man kann auch die Existenz eines gefliesten Raumes oder Kachelofens in dessen Bereich in Betracht ziehen. Die analysierten Fliesen- und Kachelfragmente wurden als lokale Produktion bestimmt, technologisch interessant ist die Verwendung von Abfall aus der Glasproduktion wie Magermittel in den Fliesen. 
Wir danken Frau Doz. RNDr. Miroslava Gregerová für ihre Beratung bei der mikropetrographischen Analyse der Keramik.

Der vorliegende Beitrag entstand im Rahmen des Projektes NAKI II „Hochmittelalterliche Keramik als Bestandteil des beweglichen Kulturerbes“ Nr. DG18P02OVV020.

Mgr. Kateřina Těsnohlídková, Ústav archeologie a muzeologie Filozofické fakulty Masarykovy univerzity, Arne Nováka 1, 60200 Brno, Česká republika, tesnohlidkova@mail.muni.cz

Mgr. Karel Slavíček, Ústav archeologie a muzeologie Filozofické fakulty Masarykovy univerzity, Arne Nováka 1, 60200 Brno; ÚGV PřF MU, Kotlářská 267/2, 61137 Brno, Česká republika, slav.karel@mail.muni.cz

Mgr. Dalibor Všianský, Ph.D., Ústav geologických věd Př́rodovědecké fakulty Masarykovy univerzity, Kotlářská 267/2,61137 Brno, Česká republika,dalibor@sci.muni.cz 
